\title{
Multiproxy studies of Early Miocene pedogenic calcretes in the Santa Cruz Formation of southern Patagonia, Argentina indicate the existence of a temperate warm vegetation adapted to a fluctuating water table
}

\author{
M. Sol Raigemborn ${ }^{\mathrm{a}, \mathrm{b}, *}$, Verónica Krapovickas ${ }^{\mathrm{c}}$, Elisa Beilinson ${ }^{\mathrm{a}, \mathrm{d}}$, Lucía E. Gómez Peral ${ }^{\mathrm{a}, \mathrm{e}}$, \\ Alejandro F. Zucol ${ }^{\mathrm{f}}$, Luciano Zapata ${ }^{\mathrm{a}, \mathrm{g}}$, M. Richard F. Kay ${ }^{\mathrm{h}, \mathrm{i}}$, M. Susana Bargo ${ }^{\mathrm{j}, \mathrm{k}}$, \\ Sergio F. Vizcaíno ${ }^{\mathrm{j}, 1}$, Alcides N. Sial ${ }^{\mathrm{m}}$ \\ a CONICET - UNLP, Centro de Investigaciones Geológicas, Diagonal 113 n.o 275, (1900) La Plata, Argentina

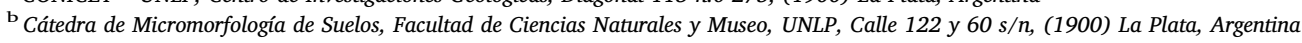 \\ ${ }^{c}$ IDEAN - CONICET, Departamento de Ciencias Geológicas, FCEyN, UBA, Ciudad Universitaria, Pabellón 2, (C1428EHA) Buenos Aires, Argentina \\ d Cátedra de Sedimentología Especial, Facultad de Ciencias Naturales y Museo, UNLP, Calle 122 y $60 \mathrm{~s} / \mathrm{n}$, (1900) La Plata, Argentina \\ e Cátedra de Sedimentología, Facultad de Ciencias Naturales y Museo, UNLP, Calle 122 y $60 \mathrm{~s} / \mathrm{n}$, (1900) La Plata, Argentina \\ ${ }^{\mathrm{f}}$ CICyTTP - CONICET, Laboratorio de Paleobotánica, Centro de Investigaciones Científicas y Transferencia de Tecnología a la Producción, Dr. Materi y España s/n, \\ (E3105BWA) Diamante, Argentina \\ ${ }^{g}$ Cátedra de Fundamentos de Geología, Facultad de Ciencias Naturales y Museo, UNLP, Calle 122 y 60 s/n, (1900) La Plata, Argentina

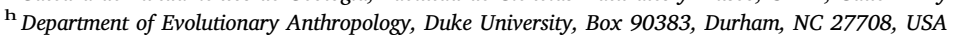 \\ i Division of Earth and Ocean Sciences (Nicholas School of the Environment), Duke University, Box 90383, Durham, NC 27708, USA \\ j (FCNyM - UNLP) División Paleontología de Vertebrados, Museo de La Plata, Unidades de Investigación Anexo Museo, UNLP, Calle 122 y 60 s/n, (1900) La Plata, \\ Argentina \\ ${ }^{\mathrm{k}}$ CIC, Argentina \\ ${ }^{1}$ CONICET, Argentina \\ ${ }^{\mathrm{m}}$ NEG - LABISE, Department of Geology, University of Pernambuco, Av. Acadêmico Hélio Ramos, s/n, (50670-000) Recife, PE, Brazil
}

\section{A R T I C L E I N F O}

\section{Keywords:}

Micromorphology

Stable isotopes

Phytoliths

Coastal vegetation

Mid-Miocene Climatic Optimum

\begin{abstract}
A B S T R A C T
The Lower Miocene Santa Cruz Formation in southern Patagonia (Austral Basin, Argentina) contains several horizons of pedogenic calcretes, which record -17.5 myr old vegetation adapted to a shallow and fluctuating water table at paleolatitude of $56^{\circ} \mathrm{S}$. To reconstruct the paleoenvironment, paleoclimate and paleoecosystem, we performed a multiproxy study of the calcretes examining abiotic and biotic components. The calcretes exhibit a variety of morphologies (horizontal and vertical rhizoliths, laminar structure, nodules, massive crusts), microfabrics (Beta- predominant over Alpha-microfabrics), and $\delta^{18} \mathrm{O}$ and $\delta^{13} \mathrm{C}$ values that fluctuate within each morphotype and throughout the analysed interval. Microfossils and phytoliths in the host material of the calcretes indicate fluctuating terrestrial, freshwater, and marine conditions, and record an ecosystem dominated by herbaceous plants and arboreal elements in association with a typical coastal "Santacrucian" vertebrate fauna. We propose that the calcretes developed in soils in a coastal/fluvial setting during pauses in floodplain aggradation that typically lasted between 8-25 ka and 400 ka years. Variable sedimentation rates in different parts of the coastal/fluvial floodplain, the fine texture of the host sediment, and the influence of a fluctuating water table also influenced the formation of the calcrete. A high water table in low relief areas of the floodplain created the conditions necessary to form a horizontally extended rhizolithic system that, jointly with the biotic proxy, can be correlated with a radicular pattern similar to the arboreal elements from coastal settings. Abiotic and biotic proxies of the studied interval attest to environmental fluctuations recorded at different scales that took place under temperate warm and subhumid climates with a marked rainfall seasonality, with a slight increase in the aridity towards the top of the studied interval. Under these conditions a subtropical fauna and a $\mathrm{C}_{3}$-dominated ecosystem developed coincident with the onset of the Mid-Miocene Climatic Optimum in Patagonia.
\end{abstract}

\footnotetext{
* Corresponding author.

E-mail address: msol@cig.museo.unlp.edu.ar (M.S. Raigemborn).
} 


\section{Introduction}

Calcretes are very common in the geological record and in modern environments (Watts, 1980; Alonso-Zarza and Wright, 2010). They can occur in different sedimentary continental settings such as alluvial fans and floodplains, and are the result of the precipitation of calcite and/or dolomite in soils and sediments (e.g. Alonso-Zarza and Wright, 2010 and references herein). The study of calcretes has become an important tool for the reconstruction of past environments (e.g. Esteban and Klappa, 1983; Machette, 1985; Alonso-Zarza et al., 2008; Alonso-Zarza and Wright, 2010; Adamson et al., 2015; Sacristán-Horcajada et al., 2016). Their isotopic composition is used for paleoclimatic reconstructions and for the interpretation of ancient ecosystems (AlonsoZarza, 2003; Wright, 2007; Gocke et al., 2011; Horn et al., 2013; Huerta et al., 2015; Li et al., 2015). Phytolith assays of the host material of calcretes are also useful to reconstruct paleovegetation, to determine the relative proportion of $\mathrm{C}_{3}$ and $\mathrm{C}_{4}$ plants in a given area, and to establish ecosystem changes (Quade et al., 1989; Cerling and Quade, 1993; Cotton et al., 2014). In pedogenic calcretes and in other types of paleosols, plants can generate rhizoliths (sensu Klappa, 1980), which comprise a variety of organo-sedimentary trace fossils produced by roots (e.g. Klappa, 1980; Cohen, 1982; Mount and Cohen, 1984; Wright et al., 1995).

Root traces morphology, in combination with other pedofeatures, are very useful to assess the position of the water table (Kraus and Hasiotis, 2006; Buatois and Mangano, 2011) and establish drainage conditions (Klappa, 1980; Retallack, 2001; Genise et al., 2016; Hembree and Bowen, 2017), which in turn are important for understanding paleoclimatic conditions and for reconstructing ancient landscapes (Kraus and Hasiotis, 2006). For example, laterally spreading root-systems are characteristic of plants growing in lowland environments where the water table is shallow (Retallack, 2001; Ashley et al., 2013). In these settings.

The Santa Cruz Formation (SCF), an upper Lower Miocene unit of coastal to fluvial origin in southern Patagonia, Argentina (Raigemborn et al., 2015a), contains a rich assemblage of fossil mammals studied since the 19th Century (Vizcaíno et al., 2012). However, new data on the sedimentology (Matheos and Raigemborn, 2012; Raigemborn et al., 2015a, 2015b; Cuitiño et al., 2016a), geochronology (Fleagle et al., 2012; Perkins et al., 2012; Cuitiño et al., 2016b), paleobotany (Brea et al., 2012, 2017; Zucol et al., 2015), ichnology, and paleosols (Krapovickas, 2012; Zapata et al., 2016) has recently contributed to an improved understanding of the paleoenvironments of the southernmost exposures of the costal SCF.

In this area, the SCF has calcrete-rich strata that display an extensive horizontal pattern (Raigemborn et al., 2015b, 2016). The presence of these deposits raises a question: Could this calcrete system represent the ancient emplacement of a root network of vegetation adapted to a shallow water table at middle/high-paleolatitudes $\left(\sim 56^{\circ} \mathrm{S}\right.$; van Hinsbergen et al., 2015)? To tackle this issue, and in order to reconstruct the past conditions (environment, ecosystem and climate) of the calcrete-bearing SCF we performed a multidisciplinary analysis as follows: (1) We analysed the calcrete bearing sedimentary facies, facies associations and paleosols to reconstruct the depositional setting and the main pedogenic conditions; (2) We studied the macromorphology, microfabric, mineral composition and other features of the calcretes together with stable isotopic data (C and $\mathrm{O}$ ) to understand the conditions under which they developed; (3) we reconstructed the paleovegetation based on phytoliths and other microfossil remains, including the habitat that the coastal "Santacrucian" fauna, and the paleoclimate under which it developed.

\section{Geological setting}

The Austral Basin is located in southernmost South America (Fig. 1A-B). This basin developed in two major phases: a rift stage during the early Cretaceous followed by a foreland stage during the late Cretaceous and Cenozoic (Biddle et al., 1986). During the Cenozoic, the basin was infilled with marine sediments deposited during several Atlantic transgressions that are variously intercalated with intervals of non-deposition, erosion, and continental deposition (Malumián, 1999). More specifically, during the Lower Miocene, the Austral Basin was infilled with marine deposits of the Monte Léon Formation (Bertels, 1970), which were transitionally succeeded by the Miocene continental deposits of the SCF (Matheos and Raigemborn, 2012; Raigemborn et al., 2015a). The Upper Miocene-Pleistocene marine and glaciofluvial sediments of the Cape Fairwether Formation and the "Rodados Patagónicos" (Fig. 1C) disconformably overlie the SCF.

The SCF crops out extensively along the Atlantic coastal cliffs in southern Santa Cruz Province (Fig. 1B) as a $\sim 225$ m-thick succession composed mainly of stacked fluvio/alluvial deposits intercalated with paleosols (Genise and Bown, 1994; Tauber, 1994; Matheos and Raigemborn, 2012; Raigemborn et al., 2015a, 2015b; Zapata et al., 2016), beginning in the lower part of the Formation as a coastal (e.g. estuarine) environment (Raigemborn et al., 2015a; Cuitiño et al., 2016a). In the study area (Puesto Estancia La Costa locality, PLC: $51^{\circ} 11^{\prime} 31^{\prime \prime} \mathrm{S}$; $69^{\circ} 6^{\prime} 34^{\prime \prime} \mathrm{W}$; Fig. 1B), the SCF outcrops are $68 \mathrm{~m}$ thick and correspond to the lower and middle parts of the unit, ranging in age from $\sim 17.5$ to $16.89 \mathrm{Ma}$ (Perkins et al., 2012; Raigemborn et al., 2015b; Fig. 2). These beds, which are rich in vertebrate assemblages, are exposed both along the sea cliffs and in the intertidal zone; the base of the SCF is not exposed (i.e., the contact with the Monte León Formation is buried) while its top is truncated by the "Rodados Patagónicos" (Fig. 1C and 2).

\section{Materials and methods}

Three sedimentary sections (PLC-1, PLC-2 and PLC-3) were studied (Fig. 2). Facies and facies associations were described following Miall (1996) and Bridge (2003) with modifications for pyroclastic deposits (Smith, 1987). Paleosols were identified based upon macroscopic structure, rhizoliths, nodules, bioturbation and color. Paleosol and rock colors were determined using the Munsell Soil- and Rock- Color Chart (2013). In order to define the composition of the rocks and paleosols of the studied succession (Fig. 2), eleven samples were microscopically analysed with a Nikon Eclipse E-200 polarizing microscope, and nine samples were analysed using X-Ray diffraction (XRD) following the methodology described in Raigemborn et al. (2014). Diffractograms were run on X PANanalytical model X'Pert PRO diffractometer, using $\mathrm{Cu} / \mathrm{Ni}$ radiation and generation settings of $40 \mathrm{KV}$ and $40 \mathrm{~mA}$.

In the study sites, the calcretes crop out in the intertidal zone of the beach and in the cliff (Fig. 2). Their geometry, shape and size were described and sampled. The most prominent morphologic features of the paleosol carbonates was interpreted as different morphological stages, which reflects calcretes degree development (Gile et al., 1966), following the stages defined by Esteban and Klappa (1983), Machette (1985), Alonso-Zarza et al. (1998), and Birkeland (1999). Five air-dried rhizoliths and nodules were impregnated with epoxy resin, cut and polished to a slide of $1 \mathrm{~cm}$-thickness (polished hand specimens) to analyse their internal morphology. The compositional and textural features of the calcretes were investigated via micromorphological analysis of sixteen samples (Fig. 2) with a Nikon Eclipse E-200 polarizing microscope. Uncovered thin-sections of calcretes were analysed under a cold Cathodoluminiscence (CL) unit operating at $8-12 \mathrm{kV}$ with 350-550 IA beam current. For mineralogical composition and microtextures of the calcretes, samples were coated with $\mathrm{Au}$ and analysed using a scanning electron microscope (SEM) FEI Quanta 200 SEM and with X-ray energy dispersive spectroscopy (EDS) with an EDAX Phoenix 40.

The isotopic analysis (24 microsamples from eleven samples; Fig. 2 and Supplementary Dataset 1) was carried out in microtransects through rhizoliths and nodules (from the center to the outer parts), and 


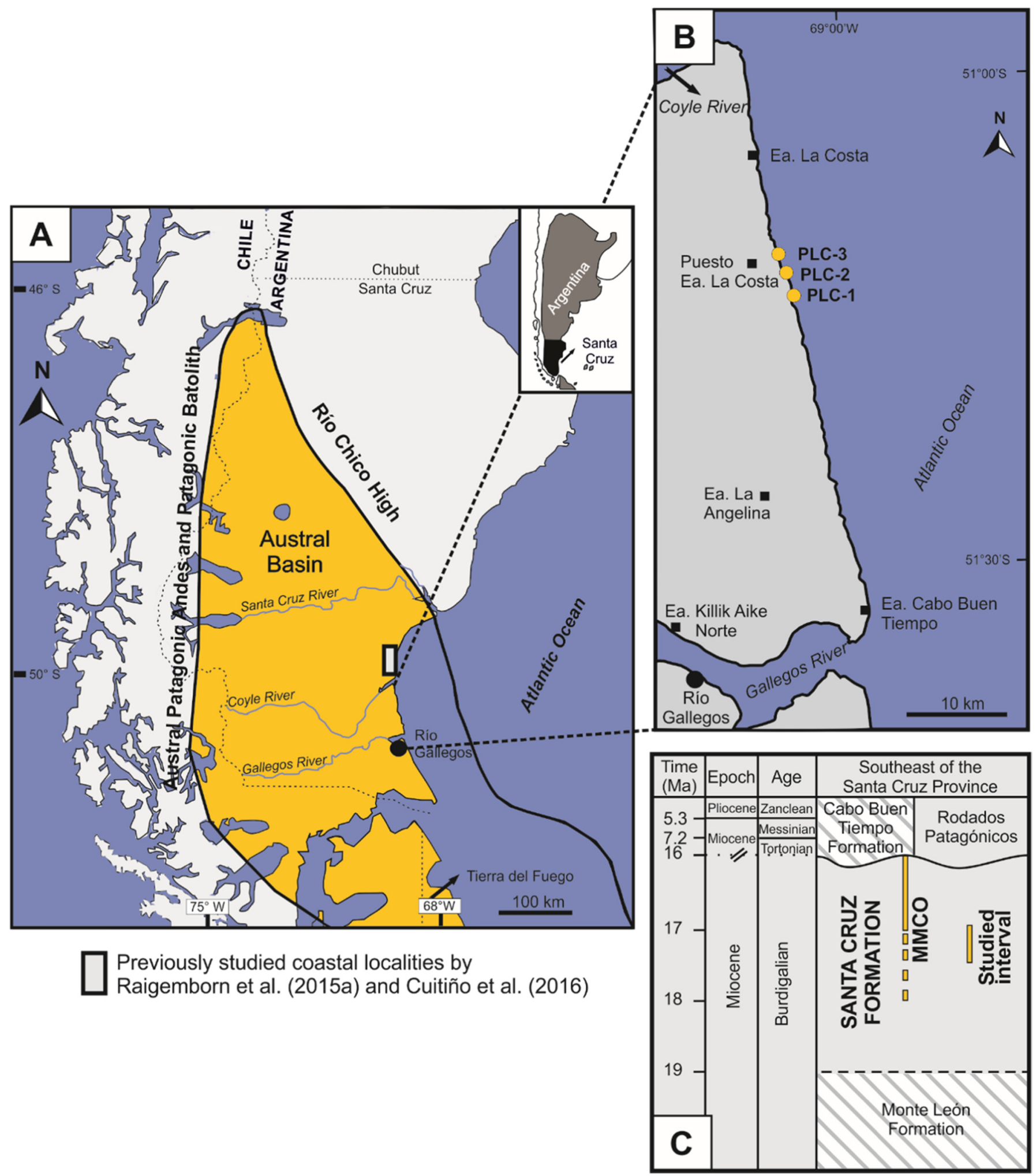

Fig. 1. A., Geographical setting of the Austral Basin. B., The study area with the three studied profiles. C., Stratigraphic sketch of the southeast Santa Cruz province with the position of the studied interval and the MMCO (Middle Miocene Climate Optimum). Striped in C corresponds to marine units.

was measured in calcretes at the Stable Isotope Laboratory (LABISE) of the Department of Geology (Federal University of Pernambuco, Brazil). Extraction of $\mathrm{CO}_{2}$ gas from powdered samples from selected unaltered microsamples was performed in a high-vacum line after reaction with $100 \%$ orthophosphoric acid at $25^{\circ} \mathrm{C}$ for one day. Released $\mathrm{CO}_{2}$ was analysed after cryogenic cleaning in double inlet, triple-collector SIRA
II or Delta V Advantage mass spectrometers and results are reported in $\delta$ notation in permil (\%) relative to the VPDB standard. The oxygen and carbon isotope ratios are expressed in $\delta$ notation, the per mil (\%o) deviation from the Vienna Pee Dee Belemnite (VPDB) standard: $\delta^{18} \mathrm{O}=\left[\left({ }^{18} \mathrm{O} /{ }^{16} \mathrm{O}\right)\right.$ sample $/\left({ }^{18} \mathrm{O} /{ }^{16} \mathrm{O}\right)$ VPDB $\left.)-1\right] \times 1000$ for oxygen and $\quad \delta^{13} \mathrm{C}=\left[\left({ }^{13} \mathrm{C} /{ }^{12} \mathrm{C}\right) \quad\right.$ sample $/(13 \mathrm{C} / 12 \mathrm{C})$ 


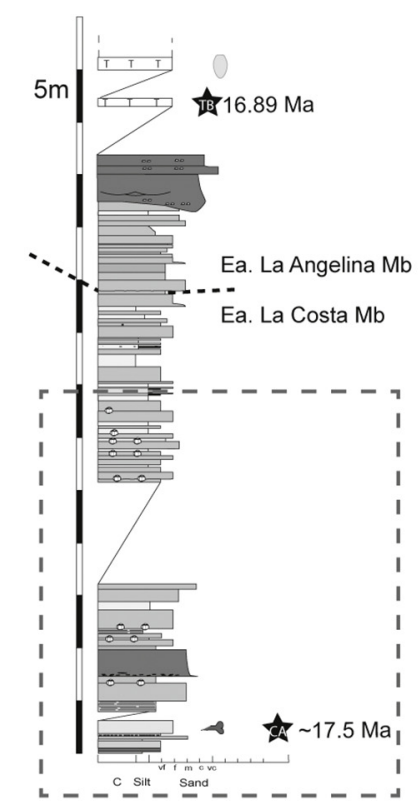

\section{PLC-3}

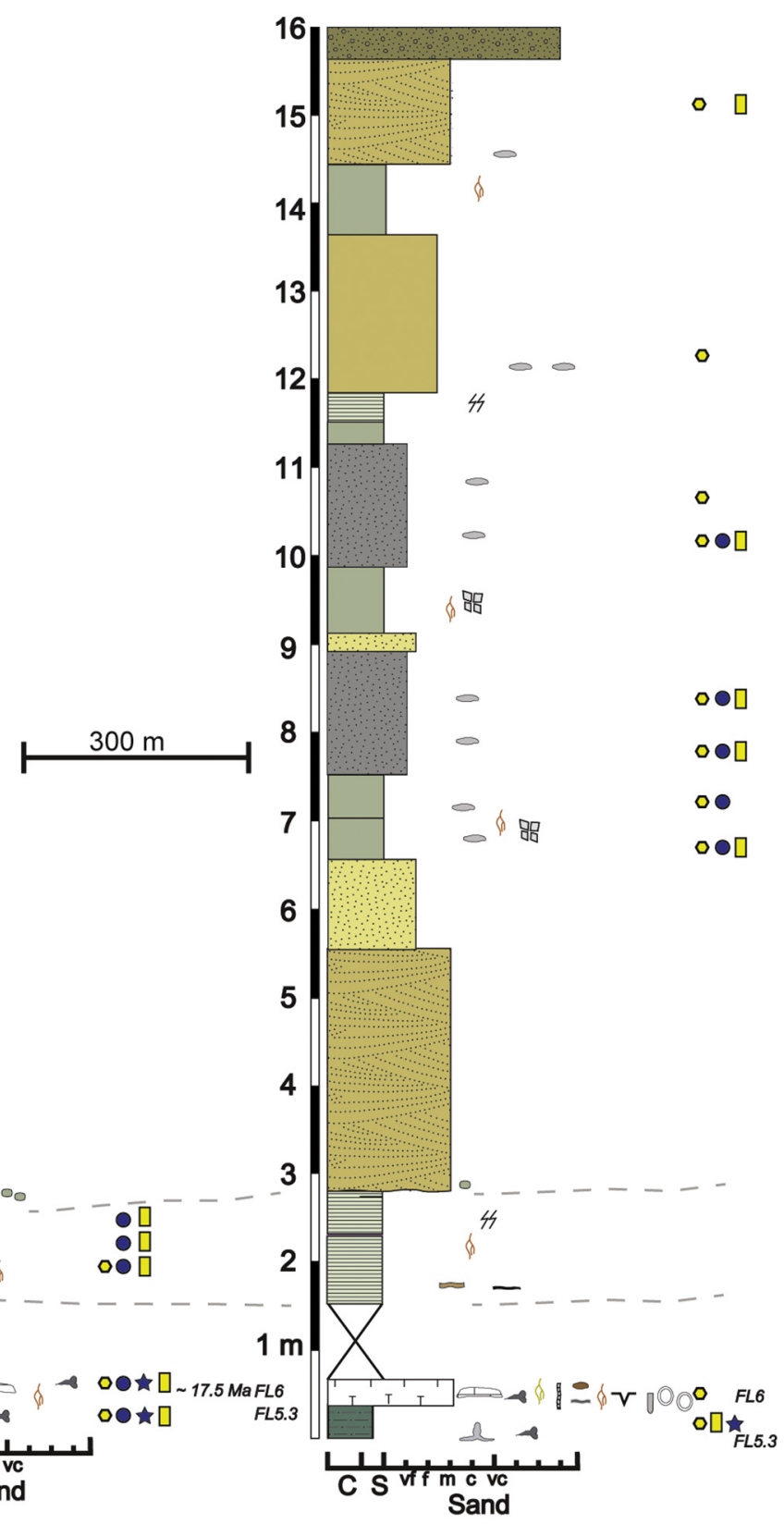

\section{$S$ PLC-1}


Sand

\section{PLC-2}

Facies

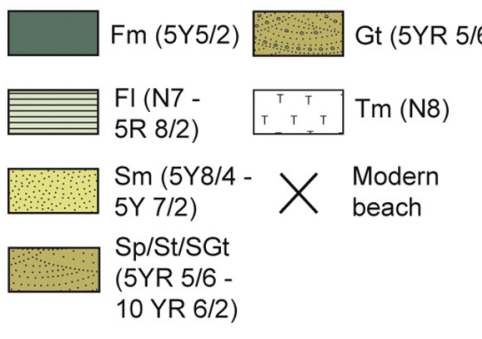

\section{Calcrete Types}

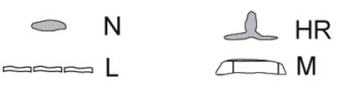

\section{Pedofeatures and trace fossils}



\section{Other features}

$\checkmark$ Dessication cracks $\rightarrow \begin{aligned} & \text { Vertebrate } \\ & \text { remains }\end{aligned} \quad$ Intraclast $t$ Ages of Perkins

\section{Samples}

Microscopic and XRD analysis

$\square$ Isotopic analysis
Phytolith and microfossil remains analysis (poor abundance)

Phytolith and microfossil remains analysis (significant abundance) 


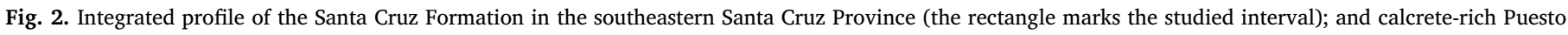
Estancia la Costa profiles (PLC-1, PLC-2, PLC-3) showing the correlated beds (interrupted lines) and the position of the analysed samples.

VPDB) -1$] \times 1000$ for carbon. Borborema skarn calcite (BSC), calibrated against international standards, was used as the reference in which the uncertainties (2 Sigma) of the isotope measurements were better than $0.1 \%$ for carbon and $0.2 \%$ for oxygen, based on multiple analyses of this internal laboratory standard. The values obtained for the standard NBS-20 in a separate run against BSC yielded $\delta^{13} \mathrm{C}$ $(\mathrm{VPDB})=-1.5 \%$ and $\delta^{18} \mathrm{O}(\mathrm{VPDB})=-4.14 \%$. The values measured were $-0.99 \%$ for $\delta^{13} \mathrm{C}$ (VPDB) and $-4.03 \%$ for $\delta^{18} \mathrm{O}$ (VPDB), with precision of 0.008 and 0.010 , respectively for $\mathrm{C}$ and $\mathrm{O}$.

The trace fossils studied are mostly preserved in the field (Fig. 2). However, the most relevant specimens were collected at the study area and stored in the Museo Regional Provincial Padre M. J. Molina (MPMPIC), Río Gallegos, Santa Cruz Province, Argentina. The material collected correspond to: 1) MPM-PIC 3635-3637, cf. Capayanichnus vinchinensis; 2) MPM-PIC 3638, a delicate root trace; and 3) MPM-PIC 3640, a calcareous rhizocretion (see Krapovickas, 2012). Rhizoliths were described and identified following Klappa (1980).

Thirteen sedimentary samples of the host rock of the calcretes (Fig. 2) were selected for phytolith analysis (twenty grams for each sample), and processed following Zucol et al.'s (2010b) protocol. Phytolith morphotypes (botanical affinity and life-form) were established based on recent contributions on woody (Mercader et al., 2009; Strömberg et al., 2013; Collura and Neumann, 2017) and herbaceous (Barboni and Bremond, 2009; Mercader et al., 2010; Neumann et al., 2017) phytolith types. Radiolarians, sponge spicules, charcoals, diatoms, and sporomorphs were also counted. Sedimentary samples and microscope slides are stored in the Paleobotanical Laboratory Collection of the Centro de Investigaciones Científicas de Diamante (CICYTTP-CONICET, Diamante), under the acronyms CIDPALBO-MS 3813-3815; 4114-4123 (see Supplementary Dataset 2).

\section{Results}

\subsection{Sedimentological context}

At Puesto Estancia La Costa, Zapata et al. (2016) described the sedimentological profile of the SCF. For the present contribution, and in order to give a sedimentological and pedological context of the calcretes, we refined the scheme of Zapata et al. (2016) adding the description (Table 1) and interpretation (next section) of macro- and micropedofeatures and the composition of the pedogenic matrix.

\subsubsection{Coastal plain/fluvial floodplain facies association (FA-1)}

4.1.1.1. Description. This FA appears throughout the analysed profiles of the SCF. It comprises four different facies. Pedofeatures and clay mineral composition of these facies are interpreted in the next section. The four facies are:

1) Sheet-like bodies (10-30 m-width; 0.1-1 m-thick) of light olive gray (5Y 5/2) massive siltstone (Fm facies; Fig. 3A-D) with vertebrate and terrestrial microfossil remains, phytoliths and pedogenic features including carbonate rhizoliths and nodules (Fig. 3A), moderate bioturbation not distinguished individually, delicate brownish Ferhizoliths (10YR 6/6; 0.5-3 mm in diameter), slickensides, organic debris scattered through the rock and an angular blocky structure (Fig. 3C-D).

2) Sheet-like bodies (2-40 m-width; 0.06-0.6 m-thick) composed of light gray (N7) to light pink (5R 8/2) claystone to siltstone with poorly preserved primary horizontal lamination (Fl facies; Fig. 3B and E), terrestrial and marine microfossil remains, phytoliths and pedogenic features such as carbonate rhizoliths and nodules of different size (Fig. 3E), burrows of Palaeophycus and delicate brown and yellowish Fe-rhizoliths (5YR 3/4 and 10YR 6/6; diameters between 0.5 and $3 \mathrm{~mm}$ ).

3) Sheet-like bodies (10-270 m-width; 0.4-2 m-thick) composed of greyish yellow to yellowish gray ( 5 Y $8 / 4$ to $5 Y$ 7/2) massive fine to medium sandstone with very sporadic pedogenic features such as carbonate nodules (Sm facies; Fig. 3A).

4) Broad sheet-like bodies (20-220 m-width; 0.3-2 m-thick) of very light gray (N8) very fine to medium-grained primary and reworked tuff, massive or sometimes with poorly preserved primary lamination (Tm facies; Fig. 3F-G). Tm facies can present intraclasts at the base; vertebrate and terrestrial and marine microfossil remains, and phytoliths are also present. Desiccation cracks and poorly defined tetrapod footprints are present at the top of some beds. This tuffaceous facies presents pedogenic features such as abundant delicate yellow Fe-rhizoliths (10YR $7 / 6 ; 0.5-3 \mathrm{~mm}$ in diameter) and common brown to reddish haloed Fe-rhizoliths (10YR 8/4 to 5YR 3/ 4; up to $7 \mathrm{~mm}$ in diameter) (Fig. $3 \mathrm{~F}$ ), slickensides, scarce carbonate rhizoliths and nodules (see next section) and occasional brownish Fe-concretions (10YR 6/6; up to $10 \mathrm{~mm}$ in diameter). The facies records locally abundant cf. Capayanichnus vinchinensis and a few examples of Taenidium barretti (Fig. 3G) and Planolites beverleyensis.

4.1.1.2. Interpretation. Fm and $\mathrm{Fl}$ facies with sheet-like shapes and nonerosive bottoms are interpreted as deposits of low-energy plain, that accumulated by settling from unconfined flows that transported fine sediment by suspension (e.g. Tunbridge, 1981). Particularly, Fl facies attest to areas of low relief of the plain (e.g. Opluštil et al., 2015). Subsequently, these deposits were subaerially exposed, bioturbated and pedogenically modified (Miall, 1996; Colinson et al., 2006). Sm facies corresponds to deposits of low-hierarchy stream-flows generated during high discharge conditions (Colinson et al., 2006) and deposited in a proximal floodplain setting, where they endured subsequent subaerial exposure and incipient pedogenic modification (Miall, 1996). Tm facies represents reworked ash-fall materials mixed with other sediments and deposited in fluvial settings in proximal floodplain areas. Deposits composed of $\mathrm{Tm}$ facies were formed by multiple flooding events of unconfined flows (Cas and Wright, 1987; Zapata et al., 2016). After deposition, subaerial exposure with loss of water content (desiccation cracks and footprints), bioturbation and pedogensis took place. The occurrence of terrestrial fossils (root traces, vertebrates, phytoliths and other microfossils) and marine microfossil remains (see after) in $\mathrm{Fl}$ and Tm deposits suggests that the lower levels of the SCF were deposited relatively closed to the coastline. Thus, this FA is interpreted as the pedogenically altered deposits of a coastal plain/distal and proximal fluvial floodplain (Table 1).

\subsubsection{Fluvial channels facies association (FA-2)}

4.1.2.1. Description. The FA-2 occurs at the middle and upper sections of the analysed SCF. It is characterized by ribbon-like to sheet-like bodies (25-1200 m-width; 2-25 m-thick) composed of light brown to pale yellowish brown (5YR 5/6 to 10YR 6/2) fine conglomerates to fine sandstones with tractive structures such as through-cross stratification (Gt, SGt, St facies) and planar-cross stratification (Sp facies) with intraclasts and carbonate concretions at the base and a slightly erosive basal contact (Fig. 3B and $\mathrm{H}$ ).

4.1.2.2. Interpretation. Gt, SGt and St facies are interpreted as the migration of 3D-dunes (gravelly, sandy-gravelly, and sandy, respectively) in fluvial channels (e.g. Miall, 1996). Sp facies corresponds to the migration of 2D-sandy dunes in fluvial channels (e.g. Miall, 1996). Carbonate concretions at the base of the bodies are interpreted as fragments of eroded pedogenic carbonate lags deposits in 


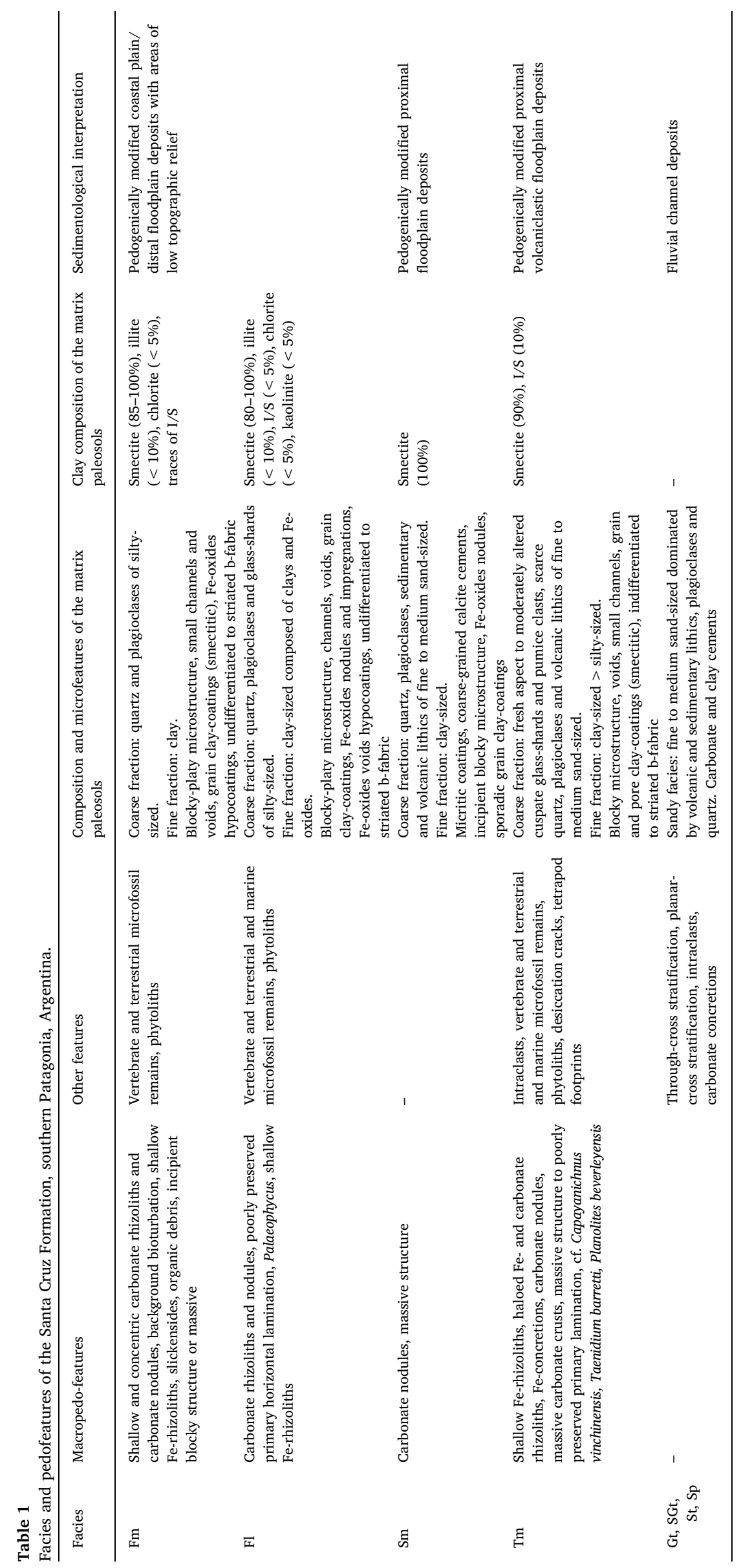





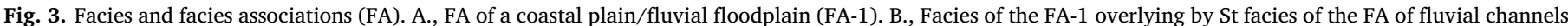




overlying by a channel of FA-2. (For interpretation of the references to color in this figure legend, the reader is referred to the web version of this article.)

non-channelized facies of the FA-1. Thus, this FA-2 corresponds to the infill of mono-episodic and low-sinuosity fluvial channels (e.g. Gibling, 2006).

\subsection{Pedological context: calcretes and their host-material}

Calcretes of the SCF consist of different pedogenic carbonates (Table 2), all of them included in the FA-1.

\subsubsection{Horizontal rhizocretions system (HR-calcretes)}

4.2.1.1. Description. Horizontal systems of rhizoconcretions outcrop in the lower parts of the analysed SCF section (Fig. 3), in the modern intertidal plain, and in Fm and Fl facies (see pedogenic features and clay mineral composition in the previous section and in Table 1). In general terms, the carbonate makes up an extensive network of at least $4 \mathrm{~km}^{2}$ (Fig. 4A). The system involves assorted structures of horizontal and vertical disposition, different angles of interconnection and sizes (Fig. 4B-D). Unfortunately, the most delicate vertical elements are incompletely preserved, mostly due to the erosive action of modern 

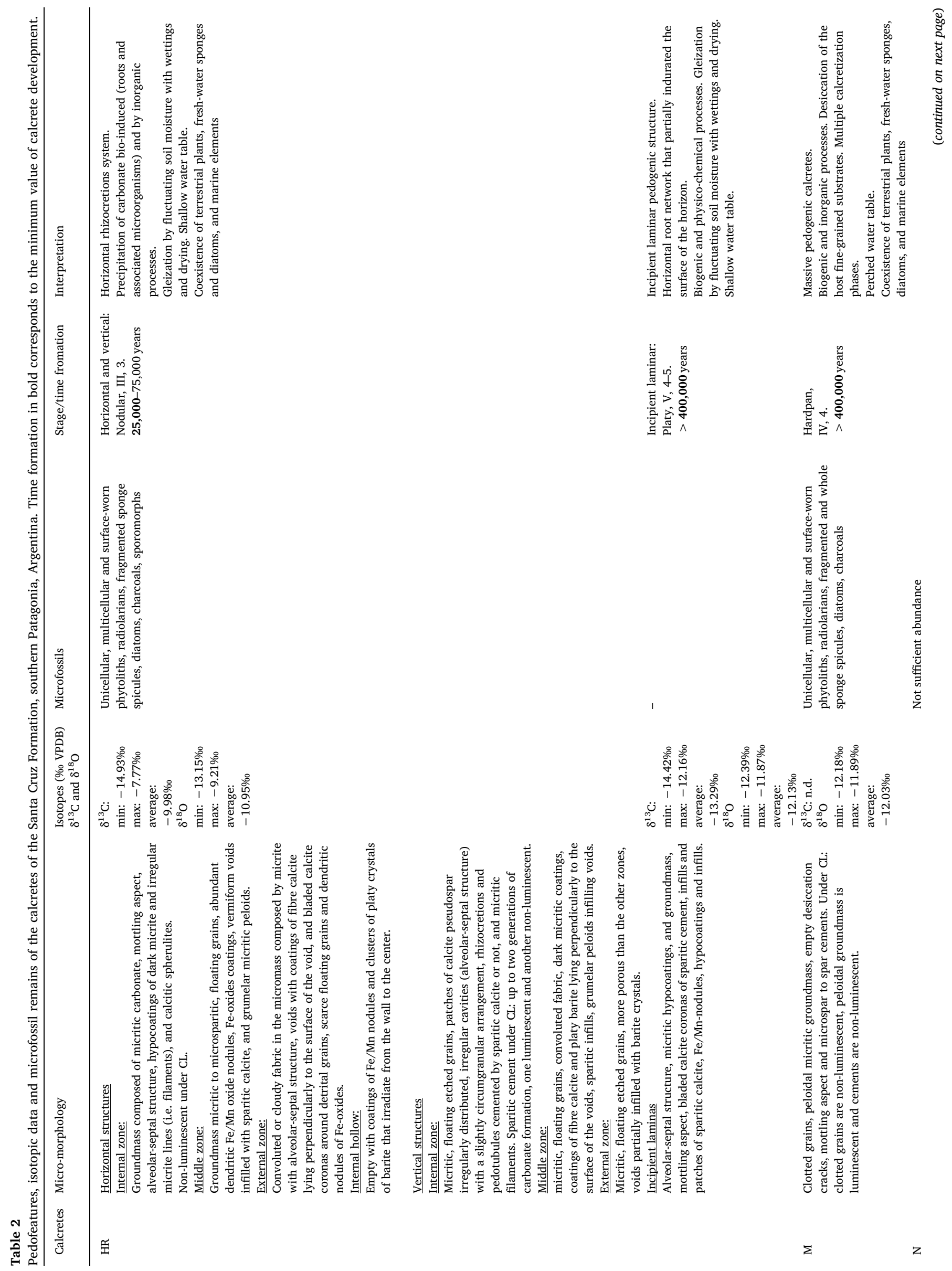

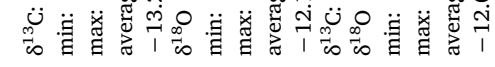


waves and tides. The host rock of these calcretes is also partly missing due to modern marine erosion; calcretes were exhumed and now they are exposed as free-standing horizontal structures. Occasionally, when the host rock is preserved, incipient laminar carbonate is present in association with horizontal structures (Fig. 4C). The dominant elements in HR-calcretes are cylindrical structures of horizontal disposition with circular-oblong sections and diameters between 1 and $5.3 \mathrm{~cm}$, but reaching up to $10 \mathrm{~cm}$ (Fig. 4B-D). They are mainly straight and less frequently curved structures, which overlap each other and are also interconnected (Fig. 4B-C). The surface is white (N8) and smooth, corrugated, or has preserved delicate and randomly arranged carbonate filaments of a few millimetres-wide. These elements frequently present vertical branches of approximately the same diameter and that are $3-30 \mathrm{~cm}$ in length/height (Fig. 4B and D; Table 2). The branching occurs from 20 to $90^{\circ}$, but most frequently at $45^{\circ}$ (Fig. 4B) and is also related to vertical carbonate structures of bigger dimensions $(10-20 \mathrm{~cm}$ in diameter) from which they occasionally radiate (Fig. 4D).

When observed in polished hand specimens, the horizontal structures present two zones. The central zone is massive, gray in color ( $5 \mathrm{Y}$ $6 / 1$ ) with vermiform cavities infilled with pale yellow (8/2 5Y) carbonate conforming a network; the external zone is massive and white (5Y 8/1) (Fig. 4E). Cross-section of the polished hand specimens of the vertical structures show that internally they present up to three concentric zones (Fig. 4F). The internal one shows an empty small hollow ( $3 \mathrm{~mm}$-diameter) which is enclosed by a tube composed of yellowish gray (5Y 7/2) carbonate. The middle zone consists of a coarser light olive gray (5Y 5/2) carbonate. The external zone is composed of a yellowish gray $(5 Y 7 / 2)$ carbonate that resembles the tube of the central zone.

Micromorphologically (Fig. 5; Table 2), HR-calcretes consist of three irregular concentric zones that present Beta- (Fig. 5A and B) and Alpha-microfabrics (Fig. 5C) and an internal hollow (Figs. 5D-F).

The incipient laminar structure is characterized by a group of white (5Y 8/1), irregular to wavy millimeter-thick layers of a chalky to well indurated material, that form a discontinuous layer over tens of centimeters-long (Table 2). Micromorphologically, Beta- and Alpha-microfabrics characterized these layers (Table 2).

4.2.1.2. Interpretation. The predominant horizontal disposition of a branched system with no downwards taper may look suspicious when interpreted as a root system. However, several morphological aspects differentiate this horizontal rhizolithic system from those of trace fossils produced by invertebrates. First, these systems differ from such arthropod-produced structures as Thalassinoides, Spongeliomorpha or Ophiomorpha by the convergence of some tunnels with major vertical structures, the upwards and downwards branching of the structures, and the frequent overlap of the branches. The lack of pellets, scratch marks or other appendicular impressions on its surface is also in agreement with the rhizoliths interpretation. Moreover, the identification of concentric carbonate zones and an empty small central area is consistent with rhizocretions (following Klappa, 1980; Cohen, 1982; Alonso-Zarza et al., 2008). The root system described strongly resembles Faviradixus robustus Uchman et al., 2012 based upon its dominantly horizontal disposition. The rhizocretions differ from Faviradixus robustus and Rhizoichnus firmus D'Alessandro and Iannone, 1982 in lacking a uniquely thick wall, in the shortness of its branches and in the more sinuous and helicoidal course of the branches on Rhizoichnus. The mostly vertical structures in HR-calcrete horizons resemble the megarhizoliths described by Alonso-Zarza et al. (2008). Macromorphologically, both are free-standing structures that present in their external surface short cylinders forming boxworks, resembling burrows enhanced or produced by wind and water (on the SCF) after exhumation. The vertical component of the SCF rhizocretion system is composed of multiple converging rhizocretions instead of having been produced by one root as in megarhizoliths. Micromorphologically, they are similarly organized with three zones instead of five as in 

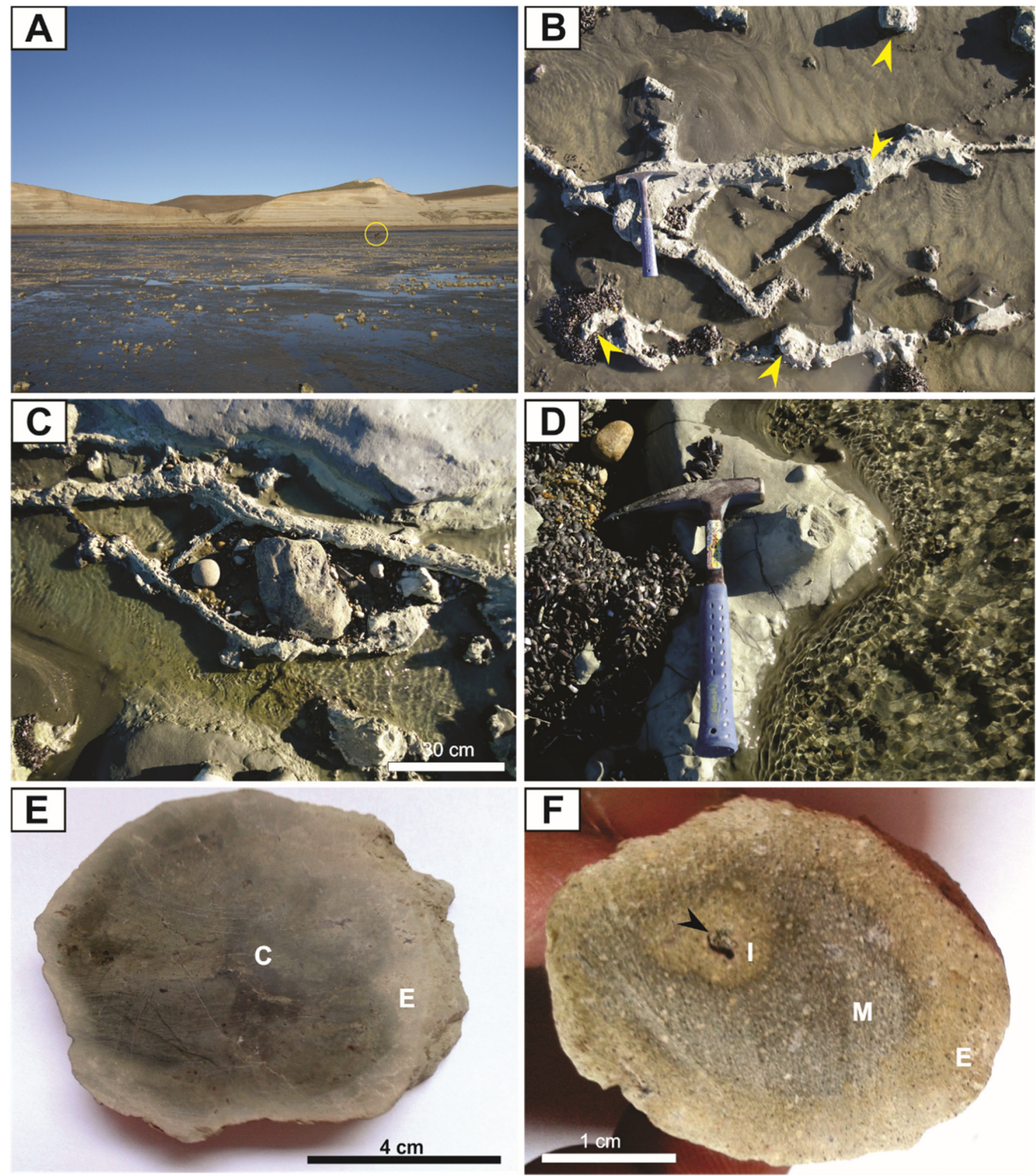

Fig. 4. Macromorphology of the horizontal rhizocretions system (HR-calcrete). A., HR-calcrete widely exposed in the modern intertidal setting at Puesto Estancia la Costa area. The circle indicates a person for scale. B., Detail of the 3D network forming by horizontal and vertical (yellow arrows) structures. C., Straight and curved horizontal structures. D., Detail of vertical branches. E and F., Polish hand-specimens of horizontal (E) and vertical (F) structures showing a central (C) and an external (E) zone in E, and a hollow (black arrow), an internal (I), a middle (M) and an external (E) zone in F. (For interpretation of the references to color in this figure legend, the reader is referred to the web version of this article.)

megarhizoliths. As was mentioned by Alonso-Zarza et al. (2008), the size of the root of the fossil plant producer is not comparable with those of the rhizoliths. For example, the size of the original root (presumably the $3 \mathrm{~mm}$-hollow in the internal zone of a conical rhizoliths) is very small in relation to the overall diameter of the rhizoliths, which is $6 \mathrm{~cm}$. The formation of an incipient laminar structure can indicate a horizontal root network that partially indurated the surface of the horizon (e.g. Alonso-Zarza and Arenas, 2004). The presence of Palaeophycus and the occurrence of organic matter and microvoids and channels at microscale in the matrix paleosol, are evidences of bioturbation.

The micromorphology of HR-calcretes and their laminar structure suggests that precipitation of carbonate may have been induced by roots and associated microorganisms (i.e. Beta-microfabrics: rhizocretions and pedotubules, alveolar-septal structure, micritic coatings and hypocoatings, micritic groundmass, filaments, fibre calcite, grumelar peloids, convoluted fabric, mottling aspect; Table 2), and inorganically (i.e. Alpha-microfabrics such as floating etched grains, bladed calcite coronas, infills and patches of calcite and sparitic calcite; and infills of barite and Fe/Mn-nodules, -coatings, -hypocoatings and -infills; Table 2). The lack of some preserved anatomical features of the roots (i.e. by root petrifaction) indicates that precipitation of calcite did not occur within or on the decaying root (e.g. Klappa, 1980). The presence of $\mathrm{Fe} / \mathrm{Mn}$-nodules, -coatings and -hypocoatings in the calcretes (Table 2) suggests gleization during their formation and is related to fluctuating soil moisture levels (Kraus and Hasiotis, 2006; Ashley et al., 

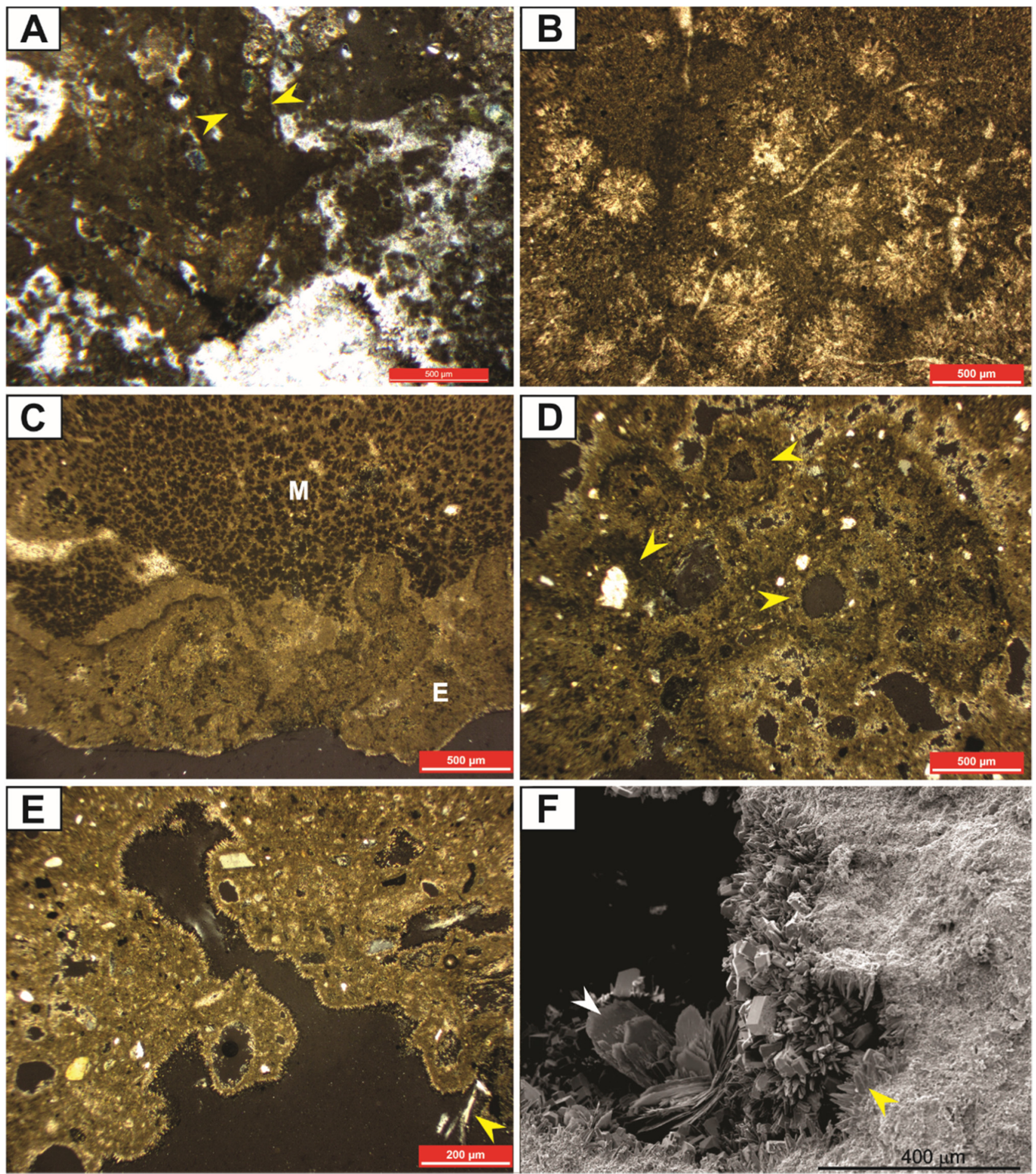

Fig. 5. Micromorphology of the horizontal rhizocretions system (HR-calcrete). A., Micritic groundmass of the internal zone with alveolar-septal structure delimited by arrows (NX, x2.5). B., Internal zone with calcitic spherulites (NX, x10). C., Middle zone (M) with Fe/Mn oxide nodules and external zone (E) with a convoluted or cloudy fabric (NX, x4). D., General aspect of the internal zone with rhizocretions and pedotubules (arrows) (NX, x4). E., Coatings of fibre calcite and platy barite (arrow) lying perpendicularly to the surface of the voids (NX, x10). F., SEM image of the middle zone showing the micritic groundmass with a void coating by fibre calcite (yellow arrow) and barite crystals (white arrow). (For interpretation of the references to color in this figure legend, the reader is referred to the web version of this article.)

2013). Multizoned calcite crystals under CL (Table 2) suggest different episodes of calcite formation. These could be linked to rapidly changing redox potentials (changes in $\mathrm{pH}$ and $\mathrm{Eh}$ ) during pedogenesis, which in turn could be related to phases of wetting and drying (Wright and Peeters, 1989; Dworkin et al., 2005). The presence of spherulites of calcite (Table 2) indicates direct exposure of the horizon to the atmosphere (Verrecchia et al., 1995; Alonso-Zarza et al., 1998; AlonsoZarza and Arenas, 2004). Barite crystals, determined by polarizing microscopic and SEM, and confirmed by EDS, (Table 2) attest to neoformation and removal of sulphate ions from the interstitial pore waters, when carbonate precipitation probably ended (e.g. Alessandretti et al., 2015). In addition, Fe-rhizohaloes and -concretions (goethite and 

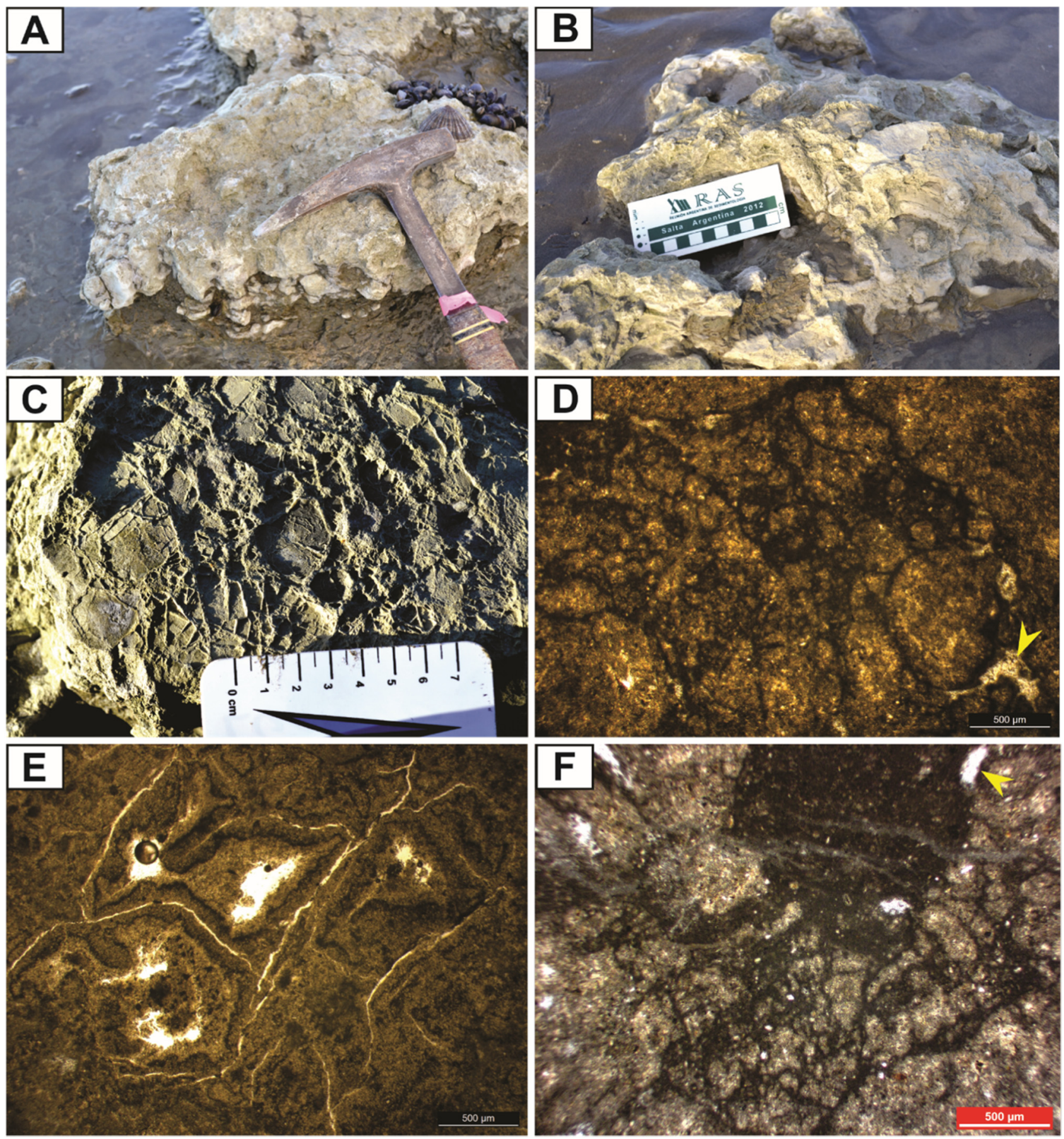

Fig. 6. Macro- (A-C) and micromorphologycal (D-F) features of the massive-calcretes (M-calcrete). A and B., Crust-like morphology in the current intertidal setting. C., Network of cracks in the upper surface of the massive-calcretes. D., Peloidal aspect of the miciritic groundmass and microspar cements (arrow) (NX, $\mathrm{x} 4)$. E., Empty micro-desiccation cracks (NX, x4). F., Mottling aspect and microspar cement (arrow) (NX, x4).

hematite) and the incipient blocky and platy structures/microstructures recorded in the matrix paleosol of the HR-calcretes, also supports the interpretation of fluctuating soil-moisture during formation (Retallack, 2001; Kraus and Hasiotis, 2006; Ashley et al., 2013). The low chroma matrix and gley colors together with Fe-oxides, the preservation of organic debris and the lack of sulphide minerals attest to soils of intermediate redox status (Retallack, 2001). The shallow distribution of the rhizoliths could be associated with relatively poor-drainage conditions (Kraus and Hasiotis, 2006; Ashley et al., 2013). These features are indicative of a partly waterlogged environment (e.g. Retallack, 2001; Stoops et al., 2010). Other pedofeatures of the matrix paleosol such as slickensides, incipient blocky macro- and microstructure, and striated b-fabrics that attest to wetting and drying cycles (Stoops et al., 2010), could be superimposed on a saturated and reducing original depositional environment that was subsequently drained and dried. Meanwhile, the presence of clay coatings of smectite suggest argilluviation.

\subsubsection{Massive calcretes (M-calcretes)}

4.2.2.1. Description. This calcrete type is characterized by a massive appearance with a crust-like morphology and is developed on fossiliferous Tm facies (Fig. 6; Table 2). Crusts are white to light gray (5Y 8/1 to 7/1) and 10-30 cm-thick (Fig. 6A-C). At the top, crusts show 
a network of planar and vertical cracks, with a reticular arrangement (Fig. 6C). Microscopically, M- calcretes present both Beta- (Fig. 6D) and Alpha-microfabrics (Fig. 6E and F) (Table 2).

4.2.2.2. Interpretation. Massive calcareous structures are considered to be pedogenic calcretes. The network of cracks is interpreted as desiccation cracks, which are related to the desiccation of the finegrained host substrates during formation (e.g. Ashley et al., 2013; Sacristán-Horcajada et al., 2016). Massive calcretes are much more resistant to weathering than the underlying sediments. Microfeatures (Table 2) such as clotted grains, peloidal micritic groundmass and mottling have a biogenic origin; meanwhile, the occurrence of Alphamicrofabrics (cracks and cements) suggests inorganic processes. Thus, the combination of both types of fabrics is considered indicative of multiple calcretization phases (e.g. Adamson et al., 2015). The different luminescence behaviours in this calcrete (Table 2) reflects variations in Mn concentration (Wright and Peeters, 1989), which is linked with redox changes.

Macro- and microfeatures and smectite-rich clay mineral composition of the matrix paleosol (see Table 1) suggest similar seasonal soil moisture fluctuations as HR-calcretes. The occurrence of cf. Capayanichnus vinchinensis, dwelling structures of crustaceans that excavated through the soil to a position below the water table, attests to abundant water at the surface or that the water table was relatively near to the surface (Hasiotis et al., 2007; Melchor et al., 2010).

\subsubsection{Nodular calcretes (N-calcretes)}

4.2.3.1. Description. The N-calcretes (Fig. 7; Table 2) are developed on $\mathrm{Fm}, \mathrm{Fl}, \mathrm{Tm}$ and Sm facies. They consist of white (N9) or medium light gray (N6) carbonate nodules dispersed in paleosols with a varied morphology (spherical-subspherical and reticulated). Nodules are sometimes isolated and sometimes coalescent; the individual diameter varies between 1 and $30 \mathrm{~cm}$ (Fig. 7A-E). Two types of nodule arrangements are distinguished: 1) densely distributed sphericalsubspherical isolated nodules in $\mathrm{Fm}, \mathrm{Fl}$ and $\mathrm{Tm}$ facies (Fig. 7A-B) that vertically transition to 2) scattered spherical-subspherical and reticulated isolated nodules with sporadic spherical-subspherical coalescent nodules in Sm facies (Fig. 7C). Spherical-subspherical nodules have a central greenish gray (5GY 6/1) zone with septarian fractures that more or less radially crosscut the nodule (Fig. 7D). This zone is massive or with a mottled aspect between fractures. Cracks are infilled by pale yellow ( $5 \mathrm{Y} 8 / 2)$ carbonate. The external zone is concentric to the internal one and it is massive and pale yellow (5Y $8 / 2$ ). Reticulated nodules are externally greenish gray (10Y 6/1) and show a fine network of cracks (up to $2 \mathrm{~mm}$-width and $8 \mathrm{~cm}$-long) (Fig. 7E). Internally, they are massive and present branching cracks that are filled by white (5Y 8/1) carbonate. A very thin light gray $(5 Y 7 / 1)$ zone covers the nodules. Microscopically, the internal zone of both types of nodules show Beta- and Alpha-microfabrics (Fig. 7F and G) whereas the external zone presents only Alpha-microfabrics (Table 2).

4.2.3.2. Interpretation. $\mathrm{N}$-calcretes are interpreted as nodular calcretes. Microfeatures such as micrite coatings and hypocoatings (Table 2) are commonly recognized in biogenic calcretes (Beta-fabric). These, adding to the previously described macrofeatures, allow us to interpret these nodules as pedogenic nodules induced by biological activity (e.g. Alonso-Zarza et al., 1998). The presence of cracks (Table 2) can be related to root penetration, but also with desiccation processes, which along with the presence of etched grains, bladed calcite coronas and sparitic cements (Alpha-fabric; Table 2) suggest inorganic processes. Thus, biogenic evidence in the nodular horizons of the SCF is limited, indicating a dominantly Alpha-fabric environment. Non-luminescent micrite and microspar in these calcretes (Table 2) suggest very low concentrations of $\mathrm{Mn}^{2+}$, which probably formed in an oxidizing and relatively dry environment in which the $\mathrm{Mn}^{2+}$ concentration was too low to act as an activator for CL (Khormali et al., 2006). However, the luminescent zones in sparite (Table 2) probably reflect phases when reduced Mn (under suboxic conditions) was incorporated into the calcite lattice (Wright and Peeters, 1989). These, together with macro- and micropedofeatures and the clay mineral composition (smectite-rich), as described for Fm, Fl and Tm facies that host nodular calcretes, indicate fluctuating soil moisture conditions and repetitive wetting and drying cycles. Of interest, in Sm facies carbonate nodules are the exclusive macropedofeature. This, adding to the high chroma of the matrix paleosol, and microfeatures such as micritic coatings and calcite cements, are linked with oxidizing conditions that attest to better-drained conditions that the other calcretes (e.g. Retallack, 2001; Ashley et al., 2013; Kraus et al., 2015). However, microfeatures such as the occurrence of incipient blocky microstructure and Fe-nodules, and clay mineral composition (Table 1) attest to wetting and drying conditions.

\subsection{Carbon and oxygen isotopic signatures of the calcretes}

The isotopic compositions of the studied calcretes cover a broad range of $\delta^{13} \mathrm{C}$ and $\delta^{18} \mathrm{O}$ values ( -15.76 to $-7.77 \%$ and $-14.42 \%$ o to $-8.86 \%$, respectively, Fig. 8A, Table 2 and Supplementary Dataset 1). $\delta^{13} \mathrm{C}$ isotopic values of HR-calcretes vary between $-14.93 \%$ and $-7.77 \%$ (average of $-10.29 \%$ ), and $\delta^{18} \mathrm{O}$ between $-13.15 \%$ and $-9.21 \%$ (average of $-10.88 \%$ ). The incipient laminar structure associated to HR-calcretes present $\delta^{13} \mathrm{C}$ isotopic values ranging from $-14.42 \%$ and $-12.16 \%$ (average of $-13.29 \%$ ), and $\delta^{18} \mathrm{O}$ from $-12.39 \%$ to $-11.87 \%$ (average of $-12.13 \% 0$ ). $\delta^{13} \mathrm{C}$ isotopic values of $\mathrm{M}$-calcretes present anomalous values, but $\delta^{18} \mathrm{O}$ is between $-12.18 \% 0$ and $-11.89 \%$ (average of $-12.03 \%$ ). $\delta^{13} \mathrm{C}$ isotopic values of nodules (N-calcretes) range from $-15.76 \%$ to $-9.55 \%$ (average of $-12.09 \%$ ); meanwhile, $\delta^{18} \mathrm{O}$ isotopic values are between $-13.36 \%$ and $-8.86 \%$ (average of $-11.49 \%$ ). HR-calcretes on average are slightly more enriched in the heavier isotopes than $\mathrm{N}$-calcretes and incipient laminas, which could suggest that the former attest to more evaporative conditions and shallower soil depths (Liu et al., 1996).

In general, $\delta^{13} \mathrm{C}$ and $\delta^{18} \mathrm{O}$ values of the analysed SCF section as a whole fluctuate widely without any clear trend (Fig. 8A). However, a slight tendency to increasing $\mathrm{C}$ and especially $\mathrm{O}$ isotopic values in the upper half of the section are notable. At a smaller scale, when analysed individually, the microtransects in rhizoliths and nodules show variable $\delta^{13} \mathrm{C}$ and $\delta^{18} \mathrm{O}$ values (Fig. 8B and C). Isotopic values changes between the concentric parts of the same rhizolith and nodule indicated that there is no isotopic exchange between layers and that the isotopic composition was preserved without influence of seawater or diagenetic modification (e.g. Wang and Zheng, 1989).

\subsection{Microfossil analysis}

Although no macroscopic vegetative and reproductive parts of plants (i.e. trunks, branches, fruits) has been preserved within the calcretes, there are phytoliths and microfossil remains (Figs. 9 and 10; Supplementary Dataset 2), mainly concentrated in the host material of the HR- and M-calcretes (Fig. 2; Table 2). N-calcretes and other paleosols do not present sufficient abundance and variability of remains to be considered in the statistical analyses (Fig. 2; Table 2).

Unicellular phytoliths are the predominant type (Fig. 9 and 10A); there are complete or fragmented spicules of freshwater sponges (Fig. 10B-F), diatoms (Fig. 10G-I), charcoal (Fig. 10J-L), radiolarian remains (formed mostly by their central nucleus) (Fig. 10M-P), abraded and multicellular phytoliths (Fig. 10Q-U and V, respectively). Occasional sporomorphs were also recorded. Two different sizes of terrestrial plant phytoliths were found. The larger ones are the most common, while the smaller ones present different degrees of preservation: the surface of some of them is completely preserved while others are worn and present large concavities that suggest a high-energy wearing agent. Multicellular phytoliths were assigned mainly to woody tissue 


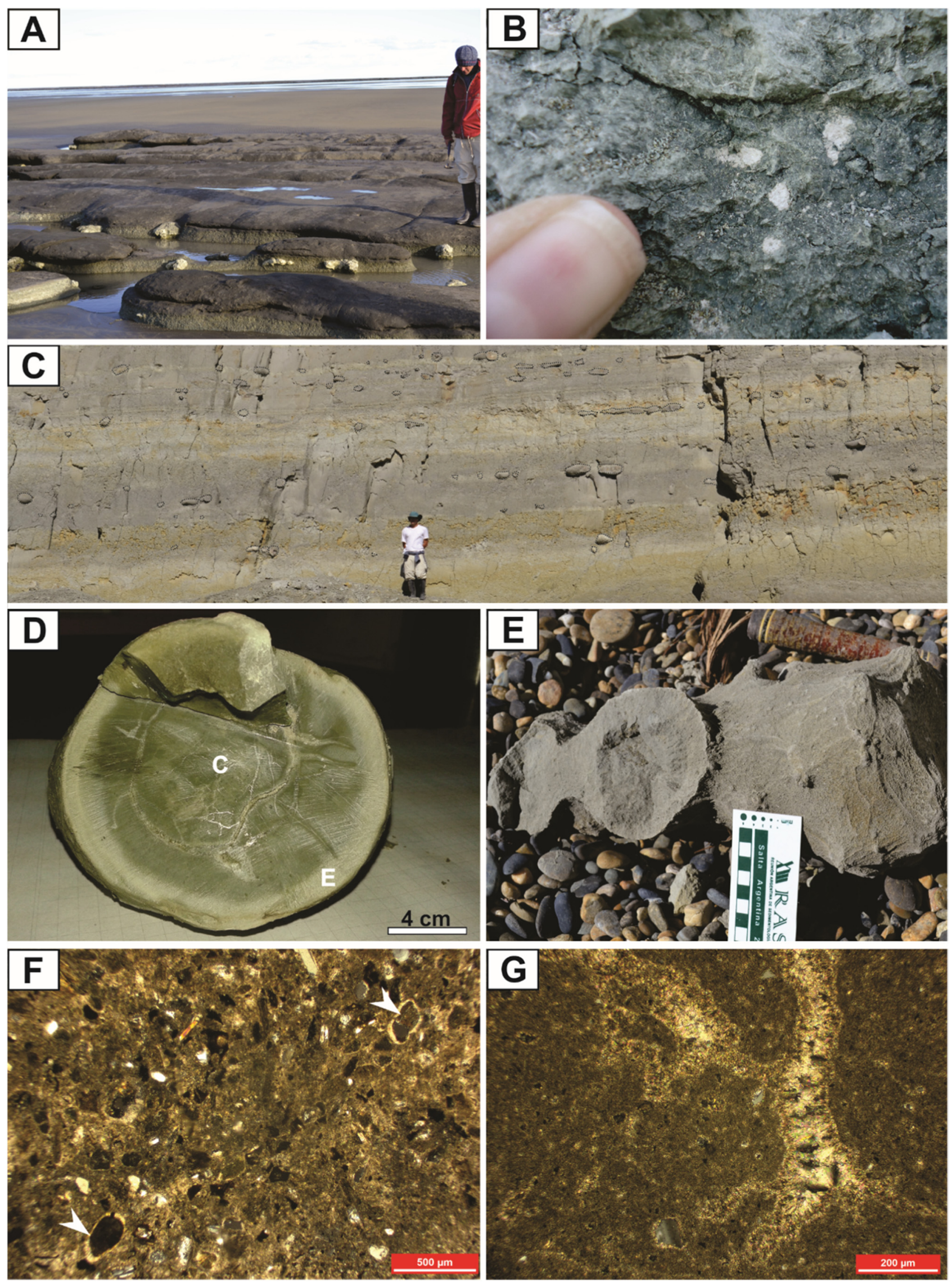




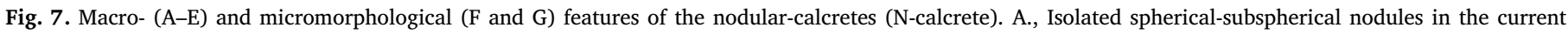

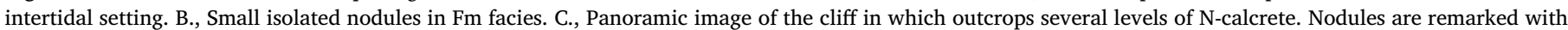

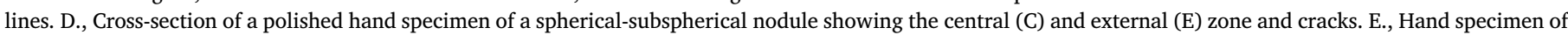


in a reticulated nodule $(\mathrm{NX}, \mathrm{x} 10)$.

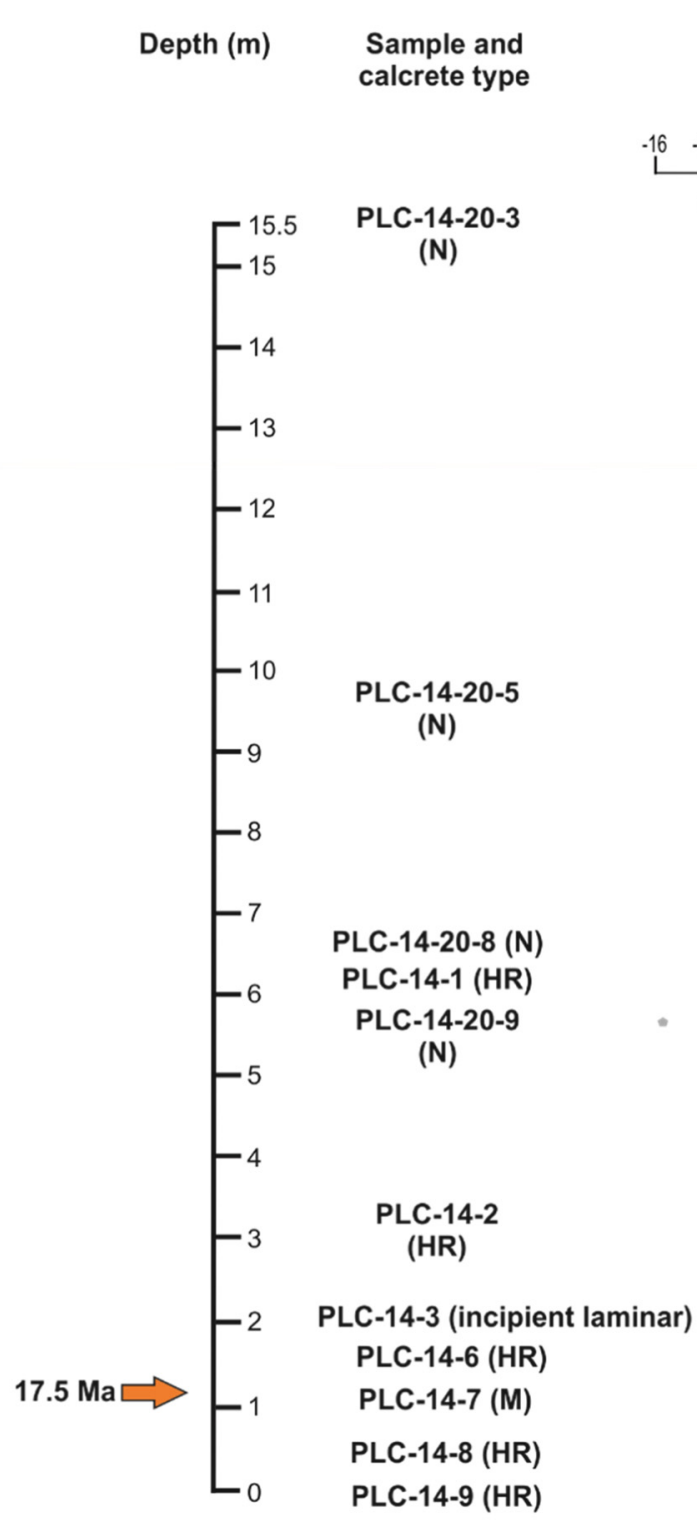



- Point microsample value $\nrightarrow$ Microsample average

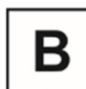

Rhizolith

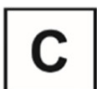

Nodule

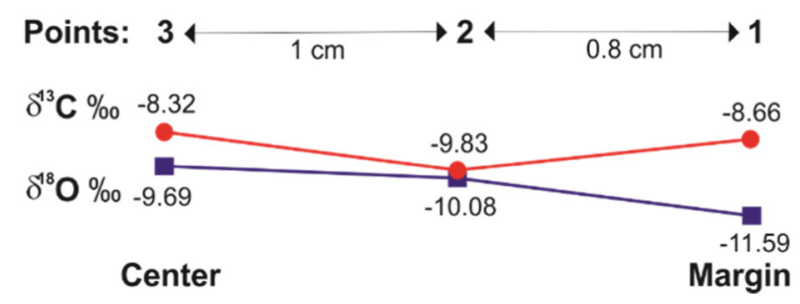

Points: $4 \longleftarrow 1 \mathrm{~cm} \longrightarrow 342 \mathrm{~cm} \longrightarrow 24 \quad 2 \mathrm{~cm} \longrightarrow 1$

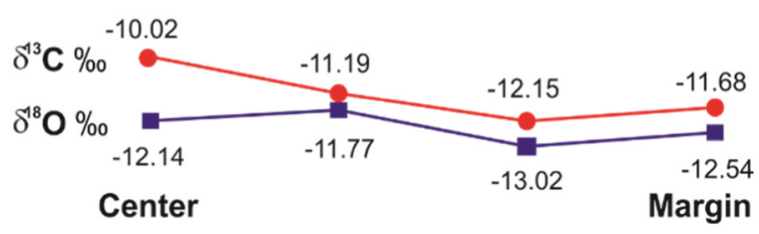



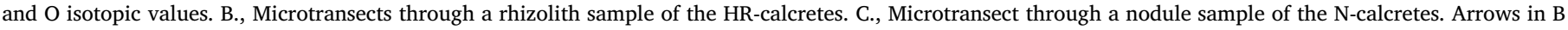
and $\mathrm{C}$ indicate distance through microtransects. 

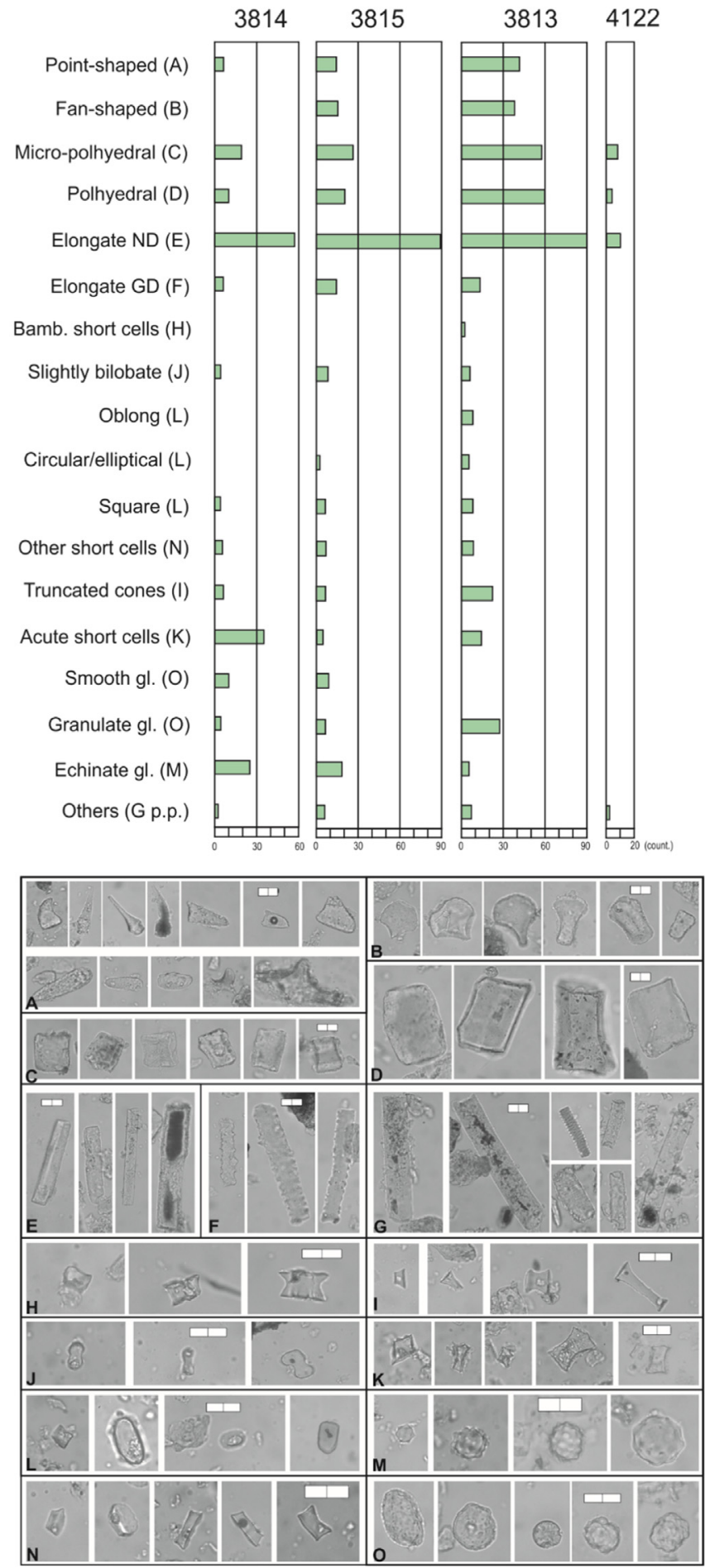

B

Fig. 9. Major unicellular phytoliths found in the calcretes of the Santa Cruz Formation. A., Morphotypes of unicellular phytoliths and their abundances in HR-calcretes, M-calcretes and laminar structures (L). B., Point-shaped phytoliths. C., Fan-shaped phytoliths. D., Micro-polyhedral phytoliths. E., Polyhedral phytoliths. F-G., Elongated phytoliths (non-diagnostic and diagnostically nongrass respectively). H., Tracheid, sclereid and vascular elements. I., Bambusoid short-celled phytoliths. J., Towers and truncated cones elements. K., Slightly bilobate phytoliths. L., Acute short-celld elements. M., Oblong, circular to elliptical and square phytoliths. N., Echinate globular elements. O., Pooids shortcelled phytoliths. P: Smooth and granulate globular phytoliths. Scale bar in all $=20 \mu \mathrm{m}$. fragments (without being able to differentiate trees or shrubs). Pointshaped (Fig. 9B), fan-shaped (Fig. 9C), micro-polyhedral (Fig. 9D), polyhedral (Fig. 9E), elongated (non-diagnostic and grasses diagnostic; Fig. 9F and G), tracheid and sclereid phytoliths (Fig. 9H) are the most abundant unicellular large morphotypes. Among the smaller and more diagnostic ones bambusoid short cells (Fig. 9I), towers and truncated cone elements (Fig. 9J), slightly bilobate (Fig. 9K), acute short cells elements (Fig. 9L), oblong, circular/elliptical, square (Fig. 9M), echinate globular elements (Fig. 9N), pooids short cells (Fig. 9O), and smooth and granulate globular phytoliths (Fig. 9P) are evident.

Thus, the microfossil analysis of the host rocks of the HR- and Mcalcretes (FA-1) reveals the coexistence of abundant terrestrial plants, freshwater spicules, diatoms, and sporomorphs and some marine elements such as radiolarians. Particularly, the features of these remains (i.e. they present only their silicified central spherical skeletons with signs of erosion) attest that the source area (the sea) was some distant to the depositional area, and that radiolarians were probably transported to landward by tidal currents, wind or spray (Girard et al., 2008). Phytoliths indicate the presence of herbaceous plants coexisting with arboreal elements; meanwhile, charcoal represents fragments of combusted organic material. A similar variety of microfossil remains is preserved in the coastal and fluvial deposits of the SCF at the Rincón del Buque locality (Zucol et al., 2015; see Fig. 1A).

\subsection{Faunal record}

Based on the tephrostratigraphic correlations of the outcrops of the SCF reported by Perkins et al. (2012), Kay et al. (2012) treated the composite vertebrate assemblages recovered from these sites, including Fm, Fl and Tm facies at Puesto La Costa (Fig. 2, Table 1), as a single fauna. They have been referred to as FL 1-7 (Kay et al., 2012) because it comprised specimens collected from sites previously considered as fossil levels (FL) 1-7 by Tauber's (1994, 1997a, 1997b). This nearsynchronous fauna contains a diverse array of insectivorous, carnivorous, and herbivorous marsupials, glyptodonts, armadillos, sloths, small and large herbivorous hippo-like astrapotheres, rabbit- to cowsized notoungulates, horse-like and camel-like litopterns, small- to medium-sized rodents, and platyrrhine monkeys (Supplementary Dataset 3).

Kay et al. (2012) reconstructed the vertebrate niche structure for FL 1-7 by identifying the number of species present, the body size, locomotion, and diet of the species. The vertebrate assemblage is dominated by mammals below $500 \mathrm{~kg}$ in body size and only one genus almost reaching a ton (Astrapotherium; Cassini et al., 2012). Kay et al. (2012) remarked that the proportion of vertebrate paleoguilds and their niche composition was equivalent to that of modern subtropical environments with a vegetation mosaic of open and closed habitats. Among them, there were forest-dwelling birds and mammals (porcupines, spiny rats, sloths, scansorial marsupials, and monkeys) and a number of taxa adapted to open environments (giant terrestrial birds, many notoungulates, glyptodonts, and armadillos). Vertebrates of this suite of localities occupied fluvial environments, as occurred at Rincón del Buque (Raigemborn et al., 2015a; see Fig. 1A).

\section{Discussion}

\subsection{The significance of the calcretes: past-environmental conditions}

Collectively, abiotic and paleobiological data (i.e. the coexistence of vertebrates, microfossil remains and phytoliths of continental and marine origin) indicate that this analysed interval of the SCF corresponds to a widely pedogenically modified coastal/fluvial plain cut by fluvial channels. The "Santacrucian" vertebrate fauna could have inhabited a riverine setting, near to the coastal area. Due to their stratigraphic position and age ( $\sim 17.5$ to older than $16.9 \mathrm{Ma})$, this system is similar to the coastal/fluvial environment described at Rincón del 

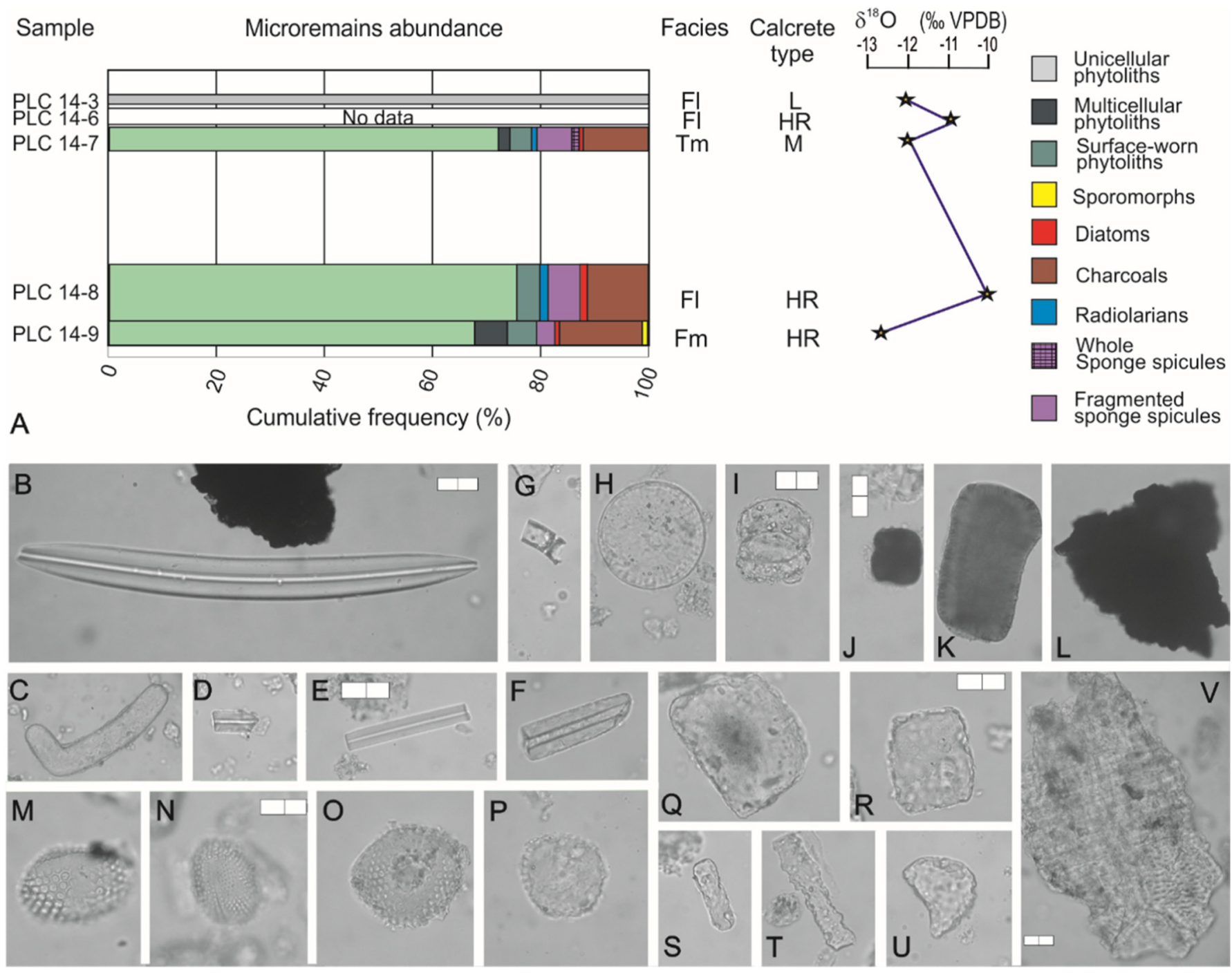

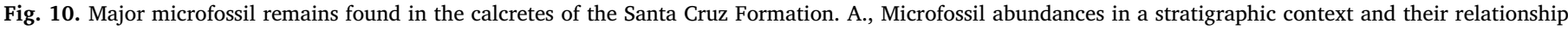

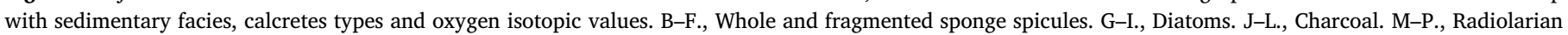
remains. Q-U., Surface-worn phytoliths. V., Multicellular phytoliths. All scale bars $=20 \mu \mathrm{m}$.

Buque and in other localities of the north of the Río Coyle (Raigemborn et al., 2015b; Cuitiño et al., 2016a, 2016b), $50 \mathrm{~km}$ to the north of the study area (Fig. 1A). Both biotic conditions (vertebrate fauna, microfossil remains and phytoliths) were previously recorded at Rincón del Buque (Raigemborn et al., 2015b; Zucol et al., 2015).

The occurrence of paleosols interbedded with non-modified clastic sediments attest to intervals of landscape stability (pedogenesis) that were interrupted by periods of instability (sedimentation/erosion) that buried and/or eroded the previously formed paleosols and inhibited pedogenesis. Distinct macro- and micromorphological features and formation stages of calcretes are useful indicators of development and age of soils and landscapes (Gile et al., 1966; Esteban and Klappa, 1983; Machette, 1985; Alonso-Zarza et al., 1998; Birkeland, 1999). Thus, the HR-calcretes are considered as an equivalent to the nodular stage of Esteban and Klappa (1983), and they are also equivalent to the Stage III of Machette (1985) and the Stage 3 from Alonso-Zarza et al. (1998). At this stage, the precipitation of carbonate around roots and root hairs takes place, forming rhizoliths instead of nodules. Wetting and drying of the soil favours development of shrinkage cracks and later, precipitation of carbonate within the voids. Because root morphology may be a direct indicator of the local water table conditions at the time of root growth (Cohen, 1982), the vertical and relatively short morphology reflects a shallow water table. At the same time, the lateral extended morphology of the root system can be explained as due to the lateral movement of soil water and the consequent formation of a lateral root system (Esteban and Klappa, 1983). HR-calcretes are here interpreted as weakly developed calcretes (e.g. Alonso-Zarza et al., 1998; Sacristán-Horcajada et al., 2016). This, together with the preservation of relict bedding, platy microstructure, a low degree of bioturbation and the lack of other well-developed pedofeatures (i.e. absence of thick and well-structured argillic horizons) in the matrix paleosol attest to weak-pedogenesis and relatively rapid soil formation (Retallack, 2001). However, the incipient laminar structure could be assigned to a more advanced stage of calcrete formation, such as the initial part of the platy stage of Esteban and Klappa (1983), the Stage V of Machette (1985) and the Stage 4-5 from Alonso-Zarza et al. (1998). M-calcretes are associated with the hardpan stage of Esteban and Klappa (1983), the Stage IV from Machette (1985) or Stage 4 from Alonso-Zarza et al. (1998) (Table 2). At these stages, carbonate precipitation is very intense and causes the induration of the horizon and reduction of porosity, promoting the near-waterproofing of the bed. Such a situation inhibits the infiltration of meteoric waters and leads to the occurrence of perched and episodic microwater tables above it. Thus, a continuous layer of secondary carbonate is formed producing a more developed calcrete. Finally, nodular calcretes are assigned to the chalky-nodular stage of Esteban and Klappa (1983), the Stage II-III of 
Machette (1985) and to the Stage 2-3 of Alonso-Zarza et al. (1998) (Table 2). At these stages, calcrete formation is due to the precipitation of carbonate around roots and root hairs, which produce nodules of varied morphology and size, and which can be disconnected or coalescent. The formation of a hardened nodular horizons occurs through partial coalescence of individual nodules. Pedofeatures of the matrix paleosols of the $\mathrm{N}$-calcretes refer to short pedogenesis on the order of few-several hundreds to few thousands of years (e.g. Retallack et al., 2000; Retallack, 2001). Thus, nodular calcretes are considered shortterm calcrete horizons. In addition, Gile et al. (1966), Machette (1985) and Birkeland (1999) assume that nodular calcretes (stages II-III and equivalents; see Table 2) could be formed in a period of 8000-75,000 years and that the formation period of horizontal and vertical nodules (stage III and equivalents; see Table 2) could be on the order of 25,000-75,000 years meanwhile, the time required for the formation of hardpan or massive calcretes and incipient laminas (Stage IV and V, respectively, and equivalents; see Table 2) involve > 400,000 years of soil formation.

Several allocyclic factors could induce limited pedogenic development. Typically, in rapidly aggrading successions, the low-residence time does not allow intense pedogenesis, including strong calcretization (Wright et al., 1995; Sacristán-Horcajada et al., 2016). It is probable that the stability of the channel network of the FA-2 (low-sinuosity fluvial channels) favoured the establishment of an extensive aggrading coastal/fluvial floodplain and a relatively high sedimentation rate ( $\sim 150 \mathrm{~m} \mathrm{My}^{-1}$ on average; Perkins et al., 2012; Cuitiño et al., 2016b), that was punctuated by periods without deposition. Considering this sedimentation rate, the number of recorded calcretes, the temporal studied interval $(<1 \mathrm{My}$ ) and the pedofeatures of the matrix paleosols, we assume that $\mathrm{N}$ - and HR-calcretes involve the minimum value of formation established by Gile et al. (1966), Machette (1985) and Birkeland (1999) (i.e. 8,000 and 25,000 years, respectively). Thus, these calcretes represent relatively short periods of landscape stability. On the other hand, incipient laminar structures and M-calcretes, often extend laterally for kilometres representing broad stable surfaces in the landscape over relatively long periods of time ( $\sim 400,000$ years). Within the plain environment in which $\mathrm{N}$ - and HR-calcretes developed, sedimentation was low but not so slow as to allow the formation of welldeveloped paleosols. Particularly, N-calcretes (upper part of the SCF) are found mainly in proximal areas (Sm facies) of the floodplain where sedimentation is higher and consequently, paleosols are more weakly developed; HR-calcretes (lower part of the SCF) occur exclusively in coastal/distal areas of the floodplain (Fm and Fl facies) in which paleosols are slightly more developed due to a lower sedimentation rate. This increase in the morphological complexity and degree of development of the calcretes could be interpreted as evidence of more continuous sedimentation in proximal areas than in distal ones, where constant aggradation is favoured and the formation of extensive and long-term stable surfaces is impeded. On the other hand, complex Mcalcretes and incipient laminar structures (lower part of the SCF) attest to more stable conditions on both the coastal/fluvial floodplain and water table surfaces for longer periods of time, where the rates of sedimentation, erosion and calcretization were low and balanced (e.g. Alonso-Zarza et al., 1998; Alonso-Zarza, 2003; Sacristán-Horcajada et al., 2016). These well-developed calcretes type attests to the alternation of very short periods of sedimentation with longer intervals of pedogenic modification, mainly linked with the calcretization phase. The gradual reduction in degree of development/complexity up-section (Fig. 2) suggests a progressive increase in sedimentation rate. This increase was probably a consequence of unstable climate conditions (see below). It is also probable that the general fine-grained nature of the host sediments of the SCF system might have favoured the growth of nodules instead of laminar carbonate, which is a more evolved stage calcrete (e.g. Alonso-Zarza and Arenas, 2004; Sacristán-Horcajada et al., 2016). Thus, coarser-grained facies (Sm) of the upper SCF allow the rapid formation of nodules; meanwhile the finest-grained facies (Fm and Fl) of the lower SCF lead to a slower formation of rhizoliths and incipient laminar structures (e.g. Gile et al., 1966).

Macro- and microfeatures and compositional aspects of the calcretes of the SCF are evidence of fluctuating soil moisture - alternating episodes of saturation and aeration - and thus variable drainage conditions (Tables 1 and 2). The combination of Alpha- and Beta-microfabrics identified at all the studied calcretes (Table 2) suggests that the sediments of the SCF were exposed to organic and inorganic calcrete-forming processes (e.g. Adamson et al., 2015). Probably, the intermittent interruption of the bio-induced calcretization occurred because of a water table rise (Sacristán-Horcajada et al., 2016), close to the topographic surface (up to $20 \mathrm{~cm}$-depth due to the length of the Capayanichnus in calcretes of the Tm facies). The occurrence of weakly developed calcretes took place when the rise in the water table kept place with aggradation (Wright et al., 1995). This could explain the most striking features of the calcretes of the SCF, which is the dominance of horizontally elongated structures that suggest that the root systems extended horizontally. This particular geometric pattern could be correlated with the position in the floodplain where the vegetation developed horizontal root systems probably due to a high water table (e.g. Cohen, 1982; Wright et al., 1995). Under high water table conditions, the roots developed an eco-physiologic adaptation looking for anchorage (Brea et al., 2017) and as a response to the lack of aeration (e.g. Buatois and Mangano, 2011; Ashley et al., 2013). Particularly, the lower part of the studied succession of the SCF, where horizontally distributed HR-calcretes are concentrated, suggests a periodically waterlogged clay/silt-rich host-material, which could have supported a coastal root system (see below). The plants that formed the HR-calcretes developed shallow roots that extended laterally under periodically waterlogged-conditions that alternated with better-drained conditions and carbonate precipitation. Such conditions occur in modern estuarine and floodplain soils in areas of low relief (Retallack, 2013), where both the hydraulic energy and the sedimentation rate are low (Ferreira et al., 2007). Although modern analogues of calcreting of plant root in shoreline soils are very scarce, Semeniuk (2010) described calcitised rhizoliths of estuarine vegetation. Organic debris and charcoal remains at these levels of the SCF could represent the accumulation of dead roots promoted by a high water table, as are typically formed in wetland soils. The occurrence of these organic remains together with opal-phytoliths, sporadic siliceous radiolarians, carbonate structures and fossil bones (Fig. 2; Tables 1 and 2) attest to alkaline conditions in intermittently wet soils, under which degradation/dissolution of all these components are inhibited (Retallack, 2001). Weakly-developed paleosols, as recorded at lower SCF, are usually formed in inland areas of coastal settings where the soil profiles are alternately oxidized and reduced and can support coastal/terrestrial ecosystem growth (VegasVilarrúbia et al., 2010; Retallack, 2013) (see below).

\subsection{The late Early Miocene ecosystem and climate reconstruction of Patagonia}

Climate exerts a great influence on pedogenesis and calcrete formation and in its degree of development (e.g. Retallack, 2001; Sacristán-Horcajada et al., 2016). In general, pedogenic calcretes form in climates with rainfall that varies from 50 to $1000 \mathrm{~mm} \mathrm{yr}^{-1}$ (AlonsoZarza and Wright, 2010) and temperatures ranging from very hot to cold (Zamanian et al., 2016). Very well-developed calcretes, unlike those described in this work, range between 100 and $500 \mathrm{~mm} \mathrm{yr}^{-1}$ (Sacristán-Horcajada et al., 2016). However, there are examples of calcrete precipitation associated with root pores in places with higher mean annual precipitation (Aslan and Autin, 1998). Therefore, the key to forming calcite in root channels, whatever the amount of precipitation, is the episodic drying of the soil for a sufficiently long period (Cerling and Quade, 1993; Wang et al., 2004; Kraus and Hasiotis, 2006).

The mineral composition (i.e. the great abundance of smectite, the 
absence of kaolinite and the preservation of weatherable minerals as volcanic glass and feldspars) of the matrix paleosol of the calcretes of the SCF attests to relatively warm and seasonal conditions and would suggest non-humid weathering conditions and mean annual precipitation $<1000-1200 \mathrm{~mm} \mathrm{yr}^{-1}$ (e.g. Bellosi and Gonzalez, 2010). Also, the assemblage of organic matter remains and calcretes could indicate precipitation between 250 and $1300 \mathrm{~mm} \mathrm{yr}^{-1}$ (Retallack, 2001). Macro- and microfeatures of the paleosols (i.e. a shallow network of fine roots, slickensides, haloed Fe-rhizoliths, Fe-concretions, concentric carbonate rhizoliths, striated b-fabrics, the combination of carbonate, clay minerals and ferruginous features, charcoals, multizoned calcite under CL) provides evidence of high frequency seasonality of the rainfall (e.g. Retallack, 2001; Kraus and Hasiotis, 2006; Kraus et al., 2015). Alpha-microfabrics are associated with precipitation of carbonate under arid environmental regimes (Wright and Tucker, 1991); meanwhile, Beta-microfabrics are indicative of organic processes linked to wetter climate conditions (Adamson et al., 2015). Thus, the dominance of Alpha-microfabrics in N-calcretes could represent relatively dryer intervals than the HR- and M-calcretes in which both types of fabrics are combined, but with a dominance of Beta-microfabrics. The occurrence of exclusively Beta-microfabrics in the internal zone of the HR-calcretes may also provide evidences of increased wetness and enhanced biological activity (e.g. Wright, 2007).

The general low $\delta^{13} \mathrm{C}$ values recorded at SCF (Fig. 8A; Table 2) are interpreted as corresponding to relatively humid environments that tend to have more depleted carbon isotope values than semi-arid ones (e.g. Cojan et al., 2013; Raigemborn et al., 2016). More depleted $\delta^{13} \mathrm{C}$ might represent an enhanced in precipitation meanwhile, less depleted values could record drier conditions (Fig. 8A). The general low $\delta^{18} \mathrm{O}$ values recorded at the studied calcretes (Fig. 8A; Table 2) indicate that they formed from the circulation of meteoric waters (e.g. Raigemborn et al., 2016). Large amplitude fluctuations of the $\delta^{18} \mathrm{O}$ values throughout the SCF (Fig. 8A and Table 2) is commonly taken to reflect changes in local water $\delta^{18} \mathrm{O}$, which in turn responds to temperature (e.g. Kohn et al., 2015). For example, wide variations in $\delta^{18} \mathrm{O}$ in HRand $\mathrm{N}$-calcretes could indicate meteoric waters with evaporative effects or perhaps the combination of these effects and slightly brackish water inputs. The less depleted isotopic values and the occurrence of radiolarians in the HR-calcretes of the basal analysed SCF section (sample PLC-14-8; Fig. 10A) attest to the possibility of the input of somewhat brackish water, probably by tides, in the most up-dip portion of the coastal/fluvial plain. Similar isotopic values together with evidences of desiccation processes recorded in $\mathrm{N}$-calcretes in the more inland section of the SCF (upper section; Fig. 8A) could be relate to the effect of evaporation of meteoric waters. On the other side, more depleted oxygen isotopic values in M-calcretes, laminar incipient structures and in few examples of HR- and N-calcretes (Fig. 8A) suggest precipitation from freshwater. This could reflect reduced evaporation with probably relatively more evenly distributed rainfalls, or could be associated with a relatively decrease in temperature. The explanation seems to be less convincing for M-calcretes where there are marine microfossil remains (sample PLC-14-7; Fig. 10A). Despite this apparent lack of correlation between freshwaters and microfossil remains, we argue that radiolarians could have been introduced by spray or winds from the sea in coastal environments (e.g. Girard et al., 2008). Consequently, isotopic values within the microtransects of rhizoliths and nodules (Fig. 8B and C) suggest that zonation was formed under alternating mainly meteoric water composition, which could correlate with seasonal conditions (Wang and Zheng, 1989; Wang and Greenberg, 2007; Kohn et al., 2015). This suggests a possible high- frequency (sub-millennial) cyclicity, probably related to relatively drier and more humid conditions (seasonality). Although several authors (e.g. Wang and Zheng, 1989; Wang et al., 2000, 2004; Wang and Greenberg, 2007; Peters et al., 2013; Kohn et al., 2015) suggest that such climate oscillation in isotopic values could be centennial, decadal, interannual, seasonal and daily, our scale of detail did not resolve the fine-scale resolution.
Biological data also support this climate interpretation. Several taxa of vertebrates recovered at the lower coastal "Santacrucian" fauna (e.g., the frog Calyptocephalella, the lizard Tupinambis, the anteater Protamandua, and the primate Homunculus) strongly indicate that the climate of FL 1-7 was much warmer and wetter than today, with ponds in some areas (Kay et al., 2012). The total mammalian species richness and niche composition, expressed as percentages of arboreal or scansorial, frugivorous, and grazing mammalian genera, suggest that overall rainfall was in the range of $1000-1500 \mathrm{~mm} \mathrm{yr}^{-1}$. Occurrence of forestdwelling birds and mammals and a number of taxa adapted to open environments supports this conclusion. Principal Component Analysis performed by Kay et al. (2012), suggests that FL 1-7 most closely resembles four extant faunas: Federal District, Brasilia; Puerto Páez, and Masaguaral, in the llanos of Venezuela, and Puerto Ayacucho, on the Río Orinoco, Venezuela. All four are subtropical sites with a vegetation mosaic of savannas and gallery forests with seasonal rainfall and droughts. These localities share more or less the same vegetation mosaic of open intervals interspersed by gallery forests with palms adjacent to rivers, often with seasonal flooding but also with long dry intervals. These are in concordance with the mixture of open temperate and semiarid forest reconstructed by Brea et al. $(2012,2017)$ for the lower part of the SCF ( 17.8-17.5 Ma), which grew under temperate to warm-temperate (MAT: $\sim 9-19^{\circ} \mathrm{C}$ ), semiarid-humid (MAP $\sim 940 \mathrm{~mm} \mathrm{yr}^{-1}$ ) and seasonal (length of dry season: $\sim 7$ months) conditions. Particularly, the types of phytoliths recorded and analysed from calcretes and their abundances agree with those described for coastal French Guiana (mangroves, brackish and freshwater marshes, swamps, lagoons, upland savannas and terra firme forest) (Watling and Iriarte, 2013). The arboreal elements Rhizophora racemosa (Rhizophoraceae), Avicennia germinans (Avicenniaceae) and the Combretaceae (Laguncularia racemosa, Conocarpus erecta and Terminalia guianensis) present diagnostic polyhedral epidermal forms, and in some cases granular globular, hairs, tracheid and sclereid phytoliths (such in T. guianensis). Among the herbaceous components, Montrichardia arborescens (Araceae) does not have phytoliths. However, the chloridoid Spartina brasiliensis was characterized by the presence of saddles and rondeloids/ saddeloids types and the panicoid Schizachyrium riedelii by the occurrence of bilobate, polylobate, crosses and hairs in their phytolith assemblages. In brackish water swamps and lagoons highly salt-tolerant sedge (such Eleocharis mutate and Cyperus articulates) add the presence of Cyperaceae cones, globular psilates, polyhedral, among other types, jointly with salt-grasses (Distichlys spicata, Chloridoideae) with abundant spooled/horned towers in their leaf phytoliths. Two major woody elements, Erythrina fusca (Papilionoideae: Fabaceae) and Chrysobalanus icaco (Chrysobalanaceae), have abundant epidermal diagnostic polyhedral epidermal forms, globular granular and psilate phytoliths, and phytoliths of hair bases. At the SCF, the coexistence of tracheid and sclereid, polyhedral, and smooth and granular globular phytoliths, together with diagnostic herb phytoliths such as truncated cones and horned towers, slightly bilobate, and rondeloids/saddeloids phytolith, are coincident with the morphotypes described by Watling and Iriarte (2013). The record of tracheid, sclereid, polyhedral, and smooth and granular globular phytoliths at the SCF allow us to estimate the presence of arboreal components in a coastal community. Oblong, circular/elliptical, square, bambusoid short cells and echinate globular types are also present at the SCF. Watling and Iriarte (2013) described many of these elements as originating in upland savannas and terra firme forest communities where brackish water species are replaced by freshwater marsh vegetation. Given the low representativeness of these elements, the origin of these forms was likely far distant from the place of deposition. An exception would be Arecaceae echinate globular types. Palms have been described in different environments, among them coastal/terrestrial settings. The collective sedimentological and paleobotanical evidences allow us to interpret the floral paleoecosystem of the lower SCF as a coastal/terrestrial setting (e.g. coastal marshes).

Our multi-proxy paleovegetational/paleoclimate reconstruction of 
the studied interval of the SCF ( $\sim 17.5$ to older than $16.9 \mathrm{Ma})$ based upon $\delta^{13} \mathrm{C}$ and phytoliths indicates a $\mathrm{C}_{3}$ dominated ecosystem without evidence of a significant proportion of $\mathrm{C}_{4}$ vegetation. Phytoliths indicate the presence of herbaceous plants coexisting with arboreal elements, varying in abundance in different levels. Diagnostic grass phytoliths (see Supplementary Dataset 2) were dominated by microthermal elements $\left(\mathrm{C}_{3}\right.$; pooids and danthoniods), and in lower abundance by megathermal ( $\mathrm{C}_{4}$; panicoids) ones. The $\delta^{13} \mathrm{C}$ values recorded in the analysed calcretes are comparable to those of Early-middle Miocene ecosystems integrated mainly by $\mathrm{C}_{3}$ plants with a balanced proportion of woodlands and grasslands, typical of relatively humid and temperate climate with a C isotopic signature between $-12 \%$ and $-10 \%$ (Cerling and Quade, 1993; Blisniuk et al., 2005). Carbon isotope values near to $-14 \%$ o (Supplementary Dataset 1 ), mainly recorded at HRcalcretes and laminar structures, attest to humid soils (Quade et al., 1989).

Long-term fluctuations in $\delta^{13} \mathrm{C}$ (i.e. intervals of landscape stability during which calcretes developed: $\sim 8,000$ years for N-calcretes, $\sim 25,000$ years for HR-calcretes, $\sim 400,000$ years for M-calcretes and incipient laminar structures) could relate to different levels of waterstressed conditions within a large coastal/fluvial plain occupied mainly by a $\mathrm{C}_{3}$ ecosystem. Therefore, periods of moisture-stressed conditions, either in relation to a rise in temperature controlling the evaporation, or to a rise in seasonality regulating the distribution of precipitation over the year, occurred in a broad interval during which water-stressed conditions did not exist. This agrees with the climate reconstructed for Patagonia during the Early Miocene based upon isotopic, biological and pedological data (e.g. Blisniuk et al., 2005; Barreda and Palazzesi, 2007; Brea et al., 2012; Kay et al., 2012; Palazzesi and Barreda, 2012; Matheos and Raigemborn, 2012; Vizcaíno et al., 2012; Palazzesi et al., 2014; Raigemborn et al., 2015b, 2016; Zapata et al., 2016). Proposed ecosystems for western Europe and North-America during the Early-middle Miocene, with $\mathrm{C}_{3}$ dominated ecosystems and small proportion of $\mathrm{C}_{4}$ plants (e.g. Cojan et al., 2013 and references herein; Harris et al., 2017), are similar to those of the SCF. The slight trend to increased $\delta^{13} \mathrm{C}$ values towards the top of the section (Fig. 8A) could be due to effects of low water availability, implying increased aridity and a significant proportion of $\mathrm{C}_{4}$ plants (e.g. Blisniuk et al., 2005).

Long-term fluctuation in $\delta^{18} \mathrm{O}$ of pedogenic carbonate could be mainly due to changes in physiography of the site (paleotopography, continentality) and to climate conditions (evaporation of meteoric fluids, temperature, seasonality of the rainfalls, source and type of precipitation/moisture) (e.g. Blisniuk et al., 2005; Cojan et al., 2013). The slight trend to increased $\delta^{18} \mathrm{O}$ values towards the top of the section (Fig. 8A) could record an increase in water-stressed conditions (aridity), as a combined effect of evaporation and temperature (e.g. Blisniuk et al., 2005; Cojan et al., 2013; Cotton et al., 2014; Chamberlain et al., 2014). During the Early Miocene the Patagonian sea contributed to the regional moisture in the Patagonian interior. However, the contraction of this inland sea during the Late Miocene intensified the continentality (Palazzesi et al., 2014). Thus, continentality as a controlling factor in the evidenced oxygen isotopic trend of the SCF seems to be unimportant. However, the in general less depleted oxygen isotopic values in HR-calcretes in comparison with other calcrete types could be indicative of different precipitation types between the more coastal site (small rainfalls) and the more inland one (more tropical showers or thunderstorms) (e.g. Cojan et al., 2013). Although the fall in the sea level that shifted the coastline landward was at $\sim 18 \mathrm{Ma}$ (e.g. Parras et al., 2016), there are still evidence of marine influence at the basal SCF ( $17.5 \mathrm{Ma}$; discussed before). Consequently, the trend of the oxygen isotopic values towards the more inland part of the analysed section could also show an increase in the freshwater input to the environment, as a response to the sea-level drop that follow the Early Miocene. Therefore, the oxygen isotopic tendency of the SCF could also record the decrease in the marine influence that could cause the loss of coastal areas giving place to more continental conditions. A change in a source of precipitations could produce a similar effect in the oxygen isotopic trend (e.g. Li et al., 2016). During the depositional times of the SCF the westerlies was the primary source of precipitation in the study area (Blisniuk et al., 2005). These authors have argued that a positive shift of oxygen isotopic values (and of carbon isotopic values), interpreted as intensified aridification, was caused by the rapid uplift of the Patagonian Andes in the middle Miocene ( $16 \mathrm{Ma})$. However, we do not consider a change in source moisture associated with the Andes uplift as a controlling factor in the oxygen isotopic trend of the analysed SCF, considering that the establishment of the Andes as a high topography in southern Patagonia occurred after the deposition of the coastal SCF ( $\sim 17.5$ to $16.9 \mathrm{Ma})$.

Multiproxy data from southern Patagonia record a temperate-warm and strongly seasonal subhumid climate, during the interval between $\sim 17.5$ and older than 16.9 Ma. Probably the long-term pattern of the carbon and oxygen isotopic values at the SCF, interpreted here as an increase in aridity, shows the Patagonian onset of the peak warming of the Middle Miocene Climate Optimum (MMCO) which took place between 17 and $15 \mathrm{Ma}$ (sensu Zachos et al., 2001) (Fig. 1C). During this interval global conditions were relatively warmer and probably more humid than before and after, and Antarctica was minimally or only partially glaciated (e.g. Henrot et al., 2010). Warm conditions of the MMCO with an initial warming beginning ca. $18 \mathrm{Ma}$ (e.g. Harris et al., 2017) could be favourable for the presence of ecosystems integrated by herbaceous and arboreal plants, dominated by $\mathrm{C}_{3}$ elements and minor components of $\mathrm{C}_{4}$ plants, as the recorded in the SCF and in other places worldwide (Cojan et al., 2013 and references herein; Harris et al., 2017). Following the warm phase of the MMCO, global factors such as global cooling associated with rapid Antarctic ice sheet growth and major biogeographic changes (Zachos et al., 2001) caused drastic ecological and climatic changes in Patagonia. Since at least the late Miocene times the southern Andes (local factor) would have blocked moisture from the west generating an extraordinary rain shadow eastward (on the leeward side of the mountains). This event reduces seasonal precipitations, favours grassland expansion and transforms the Patagonia in a steppe (e.g. Palazzesi and Barreda, 2012; Palazzesi et al., 2014). Consequently, the modern Atlantic coast of southern Patagonia is a cold semi-desert area, with windy and cold winters and, dry and warm summers, and the dominant vegetation is an arid shrubby-herbaceous steppe (Brea et al., 2012).

\section{Conclusions}

The lower part of the SCF ( $\sim 17.5$ to older than $16.9 \mathrm{Ma})$ at $\sim 56^{\circ} \mathrm{S}$ paleolatitude contains several calcrete horizons with different morphologies and fabrics interpreted as massive and nodular pedogenic calcretes. The horizontally extensive rhizocretion systems of the basal part of the unit occur in a coastal plain environment. Biotic components ("Santacrucian" vertebrates, phytoliths, and microfossil remains) point to a subtropical riverine environment near to a paleocoast line, with a vegetation mosaic of open and closed habitats within a $\mathrm{C}_{3}$-dominated ecosystem. The sedimentological context shows that the distribution of calcretes depended on the aggradation and sedimentation rate, position in the sedimentary system, texture of the host material, position of the water table and climate. These factors controlled calcrete development because they defined the time of subaerial exposure and the intensity of pedogenesis. Calcretes of the SCF are better developed in the coastal plain or in distal portion of the fluvial plain of a highly aggrading system, where the sedimentation is intermittent and low but not slow enough to allow the formation of relatively well-developed paleosols, and the host parent material is fine-grained. These involve stable periods in the order of $\sim 25,000$ years for the formation of HR-calcretes and $\sim 400,000$ years for the development of M-calcretes and incipient laminar structures. In proximal areas, where the host parent material is coarser-grained and sedimentation is more continuous, the rapid formation of very weakly-developed paleosols is favoured, mainly as 
carbonate nodules, which require $\sim 8,000$ years for their formation. The fluctuation of the water table in the sedimentary system controlled drainage conditions, structures and microfabrics of the paleosols. This explains the combination of well and poorly drained pedofeatures and the characteristic horizontally elongated structure of the calcretes. A high water table in an area of low relief on the plain seems to be the reason for why the fossil roots present a horizontally extended geometric pattern, which could correlated with a radicular pattern of elements from coastal settings.

The paleoecosystem and paleoclimate reconstructed from abiotic and biotic components evidences a marked environmental fluctuation with different hierarchies: one of high-frequency (sub-millennial) related to relatively drier and wetter conditions, and another of low-frequency $(8,000$ to $\sim 400,000$ years) associated mainly with a low-frequency climate cyclicity. These fluctuations, operating during $<1 \mathrm{My}$, occurred in a temperate-warm and seasonal subhumid climate with a slightly increase in the aridity towards the top of the studied interval that probably marks the onset in Patagonia of the warmest peak of the global warm Middle Miocene Climate Optimum. Sedimentology, paleopedology and fossil remains document the existence of a coastal/ fluvial ecosystem at the lower interval of the SCF $(\sim 17.5 \mathrm{Ma})$ at southern Patagonia.

Supplementary data to this article can be found online at https:// doi.org/10.1016/j.palaeo.2018.03.037.

\section{Acknowledgments}

The authors are very grateful to J. Zuazo (CONICET-UNLP) and A. Laroca (UNLP) for field assistance. The suggestions made by the reviewers D. Ibarra and T. White, and by the Editor, H. Falcon-Lang, greatly improved the quality of this manuscript. Financial and logistical support for these studies was provided by the projects PICT 2013-0389 and UNLP $11 /$ N750 to SFV, NSF 1349741 to RFK and PIP 100-523 to MSR.

\section{References}

Adamson, K., Candy, I., Whit, L., 2015. Coupled micromorphological and stable isotope analysis of Quaternary calcrete development. Quat. Res. 84, 272-286.

Alessandretti, L., Veríssimo, L., Machado, R., Felipe, V., Jamil, I., 2015. Septarian carbonate concretions in the Permian Rio do Rasto Formation: birth, growth and implications for the early diagenetic history of southwestern Gondwana succession. Sediment. Geol. 326, 1-15. http://dx.doi.org/10.1016/j.sedgeo.2015.06.007.

Alonso-Zarza, A.M., 2003. Palaeoenvironmental significance of palustrine carbonates and calcretes in the geological record. Earth Sci. Rev. 60, 261-298. http://dx.doi.org/10. 1016/S0012-8252(02)00106-X.

Alonso-Zarza, A.M., Arenas, C., 2004. Cenozoic calcretes from the Teruel Graben, Spain: microstructure, stable isotope geochemistry and environmental significance. Sediment. Geol. 167, 91-108. http://dx.doi.org/10.1016/j.sedgeo.2004.02.001.

Alonso-Zarza, A.M., Wright, V.P., 2010. Calcretes. In: Alonso-Zarza, A.M., Tanner, L.H. (Eds.), Carbonates in Continental Settings: Facies, Environments and Processes. Elsevier, Amsterdam, pp. 225-267.

Alonso-Zarza, A.M., Sanz, M.E., Calvo, J.P., Estcvez, P., 1998. Calcified root cells in Miocene pedogenic carbonates of the Madrid Basin: evidence for the origin of Microcodium b. Sediment. Geol. 16, 81-97.

Alonso-Zarza, A.M., Genise, J.F., Cabrera, M.C., Mangas, J., Martín-Pérez, A., 2008. Megarhizoliths in Pleistocene aeolian deposits from Gran Canaria (Spain): Ichnological and palaeoenvironmental significance. Palaeogeogr. Palaeoclimatol. Palaeoecol. 265, 39-51. http://dx.doi.org/10.1016/j.palaeo.2008.04.020.

Ashley, G., Deocampo, D.M., Kahmann-Robinson, J.A., Driese, S., 2013. Groundwater-fed wetland sediments and paleosols: it's all about water table. In: Driese, S.G., Nordt, L.C. (Eds.), New Frontiers in Paleopedology and Terrestrial Paleoclimatology: Paleosols and Soil Surface Analogue Systems. Society for Sedimentary Geology, Special Publication. 104. pp. 47-61.

Aslan, A., Autin, W.J., 1998. Evolution of the Holocene Mississippi river floodplain, Ferriday, Louisiana: insights on the origin of fine-grained floodplains. GSA Bull. 4 , 433-449.

Barboni, D., Bremond, L., 2009. Phytoliths of east African grasses: an assessment of their environmental and taxonomic significance based on floristic data. Rev. Palaeobot. Palynol. 158, 29-41.

Barreda, V., Palazzesi, L., 2007. Patagonian vegetation turnovers during the Paleogeneearly Neogene: origin of arid-adapted floras. Bot. Rev. 73, 31-50

Bellosi, E.S., Gonzalez, M.G., 2010. Paleosols of the middle Cenozoic Sarmiento Formation, central Patagonia. In: Madden, R.H., Carlini, A.A., Vucetich, M.G., Kay,
R.F. (Eds.), The Paleontology of Gran Barranca: Evolution and Environmental Change through the Middle Cenozoic of Patagonia. Cambridge University Press, Cambridge, UK, pp. 293-305.

Bertels, A., 1970. Sobre el "Piso Patagoniano" y la representación de la época del Oligoceno en Patagonia Austral. República Argentina. Rev. la Asoc. Geol. Argent. 25, 496-501.

Biddle, K.T., Uliana, M.A., Mitchum, R.M., Fitzgerald, M.G., Wright, R.C., 1986. The stratigraphic and structural evolution of the Central and Eastem Magallanes Basin, Southem South America. In: Foreland Basins. Blackwell Publishing Ltd., pp. 41-61. http://dx.doi.org/10.1002/978144430381. (O.ch2).

Birkeland, P., 1999. Soils and Geomorphology. Oxford University Press, New York (430 pp).

Blisniuk, P.M., Stern, L.A., Chamberlain, C.P., Idleman, B., Zeitler, P.K., 2005. Climatic and ecologic changes during Miocene surface uplift in the southern Patagonian Andes. Earth Planet. Sci. Lett. 230, 125-142. http://dx.doi.org/10.1016/j.epsl.2004. 11.015.

Book, Munsell Soil Color, 2013. Grand Rapids: Munsell Color: X-Rite, 2013, USA.

Brea, M., Zucol, A.F., Iglesias, A., 2012. Fossil Plant Studies from Late Early Miocene of the Santa Cruz Formation: Paleoecology and Paleoclimatology at the Passive Margin of Patagonia, Argentina. In: Vizcaíno, S.F., Kay, R.F., Bargo, M.S. (Eds.), Early Miocene Paleobiology in Patagonia. Hight-Latitude Paleocommunities of the Santa Cruz Formation. Cambridge University Press, pp. 104-128.

Brea, M., Zucol, A.F., Bargo, M.S., Fernicola, J.C., Vizcaíno, S.F., 2017. First Miocene record of Akaniaceae in Patagonia (Argentina): a fossil wood from the early Miocene Santa Cruz Formation and its palaeobiogeographical implications. Bot. J. Linn. Soc. $183,334-347$.

Buatois, L.A., Mangano, M.G., 2011. Ichnology: Organism-Substrate Interations in Space and Time. Cambridge University Press, Cambridge (358 pp).

Cas, R.A.F., Wright, J.V., 1987. Volcanic Successions: Modem and Ancient A Geological Approach to Processes, Products and Successions. Afien \& Unwin, London.

Cassini, G.H., Cerdeño, E., Villafañe, A.L., Muñoz, N.A., 2012. Paleobiology of Santacrucian native ungulates (Meridiungulata: Astrapotheria, Litopterna and Notoungulata). In: Vizcaíno, S.F., Kay, R.F., Bargo, M.S. (Eds.), Early Miocene Paleobiology in Patagonia. Hight-Latitude Paleocommunities of the Santa Cruz Formation. Cambridge University Press, pp. 243-286.

Cerling, T.E., Quade, J., 1993. Stable Carbon and Oxygen Isotopes in Soil Carbonate. In: Climate Change in Continental Isotopic Records. In: Swart, P.K., Lohmann, K.C. McKenzie, J., Savin, S. (Eds.), American Geophysical Union, Washington, DC, pp. $217-231$.

Chamberlain, C.P., Winnick, M.J., Mix, H.T., Chambelain, S.D., Maher, K., 2014. The impact of neogene grassland expansion and aridification on the isotopic composition of continental precipitation. Glob. Biogeochem. Cycles 28, 992-1004.

Cohen, A.S., 1982. Paleoenvironments of root casts from the Koobi fora Formation, Kenya. J. Sediment. Res. 52, 401-414.

Cojan, I.S., Bialkowski, A.N.N.E., Gillot, T.H., Renard, M.A., 2013. Paleoenvironnement and paleoclimate reconstruction for the early to middle Miocene from stable isotopes in pedogenic carbonates (Digne-Valensole basin, southeastern France). Bull. Soc. Geol. Fr. 184, 583-599.

Colinson, J.D., Nigel, M., Thompson, D., 2006. Sedimentary Structures. Terra, Harpenden, Hert. (292 p).

Collura, L.V., Neumann, K., 2017. Wood and bark phytoliths of West African woody plants. In: Quaternary International. 434. pp. 142-159 (Part B).

Cotton, J.M., Hyland, E.G., Sheldon, N.D., 2014. Multi-proxy evidence for tectonic control on the expansion of C4 grasses in Northwest Argentina. Earth Planet. Sci. Lett. 395, 41-50. http://dx.doi.org/10.1016/j.epsl.2014.03.014.

Cuitiño, J.I., Krapovickas, V., Raigemborn, M.S., Zapata, L., Fernícola, J.C., 2016a. La Formación Monte León (Mioceno temprano) como ejemplo de sistemas sedimentarios transicionales-regresivos de Patagonia Austral. VII Congreso Latinoamericano de Sedimentología y XV Reunión Argentina de Sedimentología 67.

Cuitiño, J.I., Fernicola, J.C., Kohn, M.J., Trayler, R., Bargo, M.S., Kay, R.F., Vizcaíno, S.F., 2016b. U-Pb geochronology of the Santa Cruz Formation (early Miocene) at the Río Bote and Río Santa Cruz (southernmost Patagonia, Argentina): implications for the correlation of fossil vertebrate localities. J. S. Am. Earth Sci. 70, 198-210. http://dx. doi.org/10.1016/j.jsames.2016.05.007.

D'Alessandro, A., Iannone, A., 1982. Pleistocene carbonate deposits in the area of Monopoli (Bari Province): sedimentology and palaeoecology. Geol. Romana 21, 603-653.

Dworkin, S.I., Nordt, L., Atchley, S., 2005. Determining terrestrial paleotemperatures using the oxygen isotopic composition of pedogenic carbonate. Earth Planet. Sci. Lett. 237, 56-68. http://dx.doi.org/10.1016/j.epsl.2005.06.054.

Esteban, M., Klappa, C., 1983. Subareal exposure environment. In: Scholle, P., Bebout, D. Moore, C. (Eds.), Carbonate Depositional Environments. American Association of Petroleum Geologists, Memoir, pp. 1-54.

Ferreira, T.O., Vidal-Torrado, P., Otero, X.L., Macías, F., 2007. Are mangrove forest substrates sediments or soils? A case study in southeastern Brazil. Catena 70, 79-91. http://dx doi.org/10.1016/j.catena.2006.07.006.

Fleagle, j.G., Perkins, M.E., Heizler, M.T., Nash, B., Bown, T.M., Tauber, A.A., Dozo, M.T., Tejedor, M., 2012. Absolute and relative ages of the fossils localities in the Santa Cruz and Pinturas Formations. In: Vizcaíno, S.F., Kay, R.F., Bargo, M.S. (Eds.), Early Miocene Paleobiology in Patagonia: High Latitude Paleocommunities of the Santa Cruz Formation. Cambridge University Press, Cambridge, pp. 41-58.

Genise, J.F., Bown, T.M., 1994. New Miocene scarabeid and hymenopterous nests and early Miocene (Santacrucian) paleoenvironments, Patagonian Argentina. Ichnos 3, $107-117$.

Genise, J.F., Bedatou, E., Bellosi, E.S., Sarzetti, L.C., Sánchez, M.V., Krause, J.M., 2016. The phanerozoic four revolutions and evolution of paleosol ichnofacies. In: Mángano, 
M., Buatois, L. (Eds.), The Trace-Fossil Record of Major Evolutionary Events. Topics in Geobiology 40. Springer, Dordrecht, pp. 301-370.

Gibling, M.R., 2006. Width and thickness of fluvial channel bodies and valley fills in the geological record: a literature compilation and classification. J. Sediment. Res. 76, 731-770.

Gile, L.H., Peterson, F.F., Grossman, J.B., 1966. Morphological and genetic sequences of carbonate accumulation in desert soils. Soil Sci. 101, 347-360.

Girard, V., Schmidt, A., Saint Martin, S., Struwe, S., Perrichot, V., Saint Martin, J., Grosheny, D., Breton, G., Néraudeau, D., 2008. Evidence for marine microfossils from amber. Proc. Natl. Acad. Sci. U. S. A. (45), 17426-17429. http://dx.doi.org/10.1073/ pnas.0804980105.

Gocke, M., Pustovoytov, K., Kühn, P., Wiesenberg, G.L.B., Löscher, M., Kuzyakov, Y., 2011. Carbonate rhizoliths in loess and their implications for paleoenvironmental reconstruction revealed by isotopic composition: $813 \mathrm{C}, 14 \mathrm{C}$. Chem. Geol. 283, 251-260. http://dx.doi.org/10.1016/j.chemgeo.2011.01.022.

Harris, E., Strömberg, C., Sheldon, N., Smith, S., Vilhena, D., 2017. Vegetation response during the lead-up to themiddleMiocene warming event in the Northern Rocky Mountains, USA. Palaeogeogr. Palaeoclimatol. Palaeoecol. 485, 401-415.

Hasiotis, S.T., Platt, B.F., Hembree, D.I., Everhart, M.J., 2007. The trace-fossil record of vertebrates. In: Miller, W.I.I.I. (Ed.), Trace Fossils: Concepts, Problems, Prospects. Elsevier, pp. 196-216.

Hembree, D.I., Bowen, J.J., 2017. Paleosols and ichnofossils of the upper pennsylvanianlower Permian Monongahela and Dunkard groups (Ohio, USA): a multi-proxy approach to unraveling complex variability in ancient terrestrial landscapes. PALAIOS 32, 295-320. http://dx.doi.org/10.2110/palo.2016.077.

Henrot, A.J., François, L., Favre, E., Butzin, M., Ouberdous, M., Munhoven, G., 2010. Effects of $\mathrm{CO} 2$, continental distribution, topography and vegetation changes on the climate at the middle Miocene: a model study. Clim. Past 6, 675-694. http://dx.doi. org/10.5194/cp-6-675-2010.

van Hinsbergen, D.J.J., de Groot, L.V., van Schaik, S.J., Spakman, W., Bijl, P.K., Sluijs, A., 2015. A paleolatitude calculator for paleoclimate studies. PLoS One 10 (6), e0126946. http://dx.doi.org/10.1371/journal.pone.0126946.

Horn, B.L.D., Pereira, V.P., Schultz, C.L., 2013. Calcretes of the Santa Maria Supersequence, Middle Triassic, Rio Grande do Sul, Brazil: classification, genesis and paleoclimatic implications. Palaeogeogr. Palaeoclimatol. Palaeoecol. 376, 39-47. http://dx.doi.org/10.1016/j.palaeo.2013.02.013.

Huerta, P., Rodríguez-Berriguete, Á., Martín-García, R., Martín-Pérez, A., La Iglesia Fernández, Á., Alonso-Zarza, A.M., 2015. The role of climate and aeolian dust input in calcrete formation in volcanic islands (Lanzarote and Fuerteventura, Spain). Palaeogeogr. Palaeoclimatol. Palaeoecol. 417, 66-79. http://dx.doi.org/10.1016/j. palaeo. 2014.10.008.

Kay, R.F., Vizcaíno, S.F., Bargo, M.S., 2012. A review of the paleoenvironment and paleoecology of the Miocene Santa Cruz Formation. In: Vizcaíno, S.F., Kay, R.F., Bargo, M.S. (Eds.), Early Miocene Paleobiology in Patagonia: High-Latitude Paleocommunities of the Santa Cruz Formation. Cambridge University Press, pp. 331-365.

Khormali, F., Abtahi, A., Stoops, G., 2006. Micromorphology of calcitic features in highly calcareous soils of Fars Province, southern Iran. Geoderma 132, 31-46. http://dx.doi. org/10.1016/j.geoderma.2005.04.024.

Klappa, C.F., 1980. Rhizoliths in terrestrial carbonates: classification, recognition, genesis and significance. Sedimentology 27, 613-629. http://dx.doi.org/10.1111/j.1365 3091.1980.tb01651.x.

Kohn, M.J., Strömberg, C.A.E., Madden, R.H., Dunn, R.E., Evans, S., Palacios, A., Carlini, A.A., 2015. Quasi-static Eocene-Oligocene climate in Patagonia promotes slow faunal evolution and mid-Cenozoic global cooling. Palaeogeogr. Palaeoclimatol. Palaeoecol. 435, 24-37. http://dx.doi.org/10.1016/j.palaeo.2015.05.028.

Kraus, M.J., Hasiotis, S.T., 2006. Significance of different modes of rhizolith preservation to interpreting paleoenvironmental and paleohydrologic settings: examples from Paleogene paleosols, Bighorn Basin, Wyoming, U.S.A. J. Sediment. Res. 76, 633-646. http://dx.doi.org/10.2110/jsr.2006.052.

Kraus, M.J., Woody, D.T., Smith, J.J., Dukic, V., 2015. Alluvial response to the PaleoceneEocene thermal maximum climatic event, polecat bench, Wyoming (U.S.A.). Palaeogeogr. Palaeoclimatol. Palaeoecol. 435, 177-192. http://dx.doi.org/10.1016/ j.palaeo.2015.06.021

Krapovickas, V., 2012. Ichnology of distal overbank deposits of the Santa Cruz Formation (late Early Miocene): paleohydrologic and paleodimatic significance. In: Vizcaíno, S.F., Kay, R.F., Bargo, M.S. (Eds.), Early Miocene Paleobiology in Patagonia: High Latitude Paleocommunities of the Santa Cruz Formation. Cambridge University Press, Cambridge, pp. 91-103.

Li, Z., Wang, N., Li, R., Ning, K., Cheng, H., Zhao, L., 2015. Indication of millennial-scale moisture changes by the temporal distribution of Holocene calcareous root tubes in the deserts of the Alashan plateau, Northwest China. Palaeogeogr. Palaeoclimatol. Palaeoecol. 440, 496-505.

Li, L., Garzione, C.N., Pullen, A., Chang, H., 2016. Early-middle Miocene topographic growth of the northern Tibetan Plateau: stable isotope and sedimentation evidence from the southwestem Qaidam basin. Palaeogeogr. Palaeoclimatol. Palaeoecol. 461, 201-213.

Liu, B., Phillips, F.M., Campbell, A.R., 1996. Ajo Mountains, southern Arizona: implications for paleoenvironmental change. Palaeogeogr. Palaeoclimatol. Palaeoecol. 124, 233-246.

Machette, M.N., 1985. Calcic soils of the southwestern United States. Geol. Soc. Am. Spec. Pap. 203, 1-21. http://dx.doi.org/10.1130/SPE203-p1.

Malumián, N., 1999. La sedimentación y el volcanismo terciarios en la Patagonia Extraandina, 1. La sedimentación en la Patagonia Extraandina. In: Caminos, J. (Ed.), Geología Argentina. Anales del Instituto de Geología y Recursos Minerales, pp. $557-578$.
Matheos, S.D., Raigemborn, M.S., 2012. Sedimentology and paleoenvironment of the Santa Cruz formation. In: Vizcaíno, S.F., Kay, R.F., Bargo, M.S. (Eds.), Early Miocene Paleobiology in Patagonia. Hight-Latitude Paleocommunities of the Santa Cruz Formation. Cambridge University Press, pp. 59-82.

Melchor, R., Genise, J., Farina, J., Visconti, G., 2010. Large striated burrows from fluvial deposits of the Neogene Vinchina formation, La Rioja, Argentina: a crab origin sug gested by neoichnology and sedimentology. Palaeogeogr. Palaeoclimatol. Palaeoecol. 291, 400-418. http://dx.doi.org/10.1016/j.palaeo.2010.03.010.

Mercader, J., Bennett, T., Esselmont, C., Simpson, S., Walde, D., 2009. Phytoliths in woody plants from the Miombo woodlands of Mozambique. Ann. Bot. 104, 91-113.

Mercader, J., Astudillo, F., Barkworth, M., Bennett, T., Esselmont, C., Kinyanjui, R., Grossman, D.L., Simpson, S., Walde, D., 2010. Poaceae phytoliths from the Niassa Rift, Mozambique. J. Archaeol. Sci. 37, 1953-1967.

Miall, A.D., 1996. The Geology of Fluvial Deposit: Sedimentary Facies, Basin Analysis and Petroleum Geology. Springer-Verlag, Berlin, pp. 582.

Mount, J.F., Cohen, A.S., 1984. Petrology and geochemistry of rhizoliths from PlioPleistocene fluvial and marginal lacustrine deposits, east lake Turkana, Kenya. J. Sediment. Petrol. 54, 263-275.

Neumann, K., Fahmy, A.G., Müller-Scheeßel, N., Schmidt, M., 2017. Taxonomic, ecological and palaeoecological significance of leaf phytoliths in west African grasses. Quat. Int. 434 (B), 15-32.

Opluštil, S., Lojka, R., Rosenau, N., Strnad, L., Sýkorová, I., 2015. Middle Moscovian climate of eastern equatorial Pangea recorded in paleosols and fluvial architecture. Palaeogeogr. Palaeoclimatol. Palaeoecol. 440, 328-352.

Palazzesi, L., Barreda, V., 2012. Fossil pollen records reveal a late rise of open-habitat ecosystems in Patagonia. Nat. Commun. 3 (1944). http://dx.doi.org/10.1038/ ncomms2299.

Palazzesi, L., Barreda, V.D., Cuitiño, J.I., Guler, M.V., Tellería, M.C., Ventura Santos, R., 2014. Fossil pollen records indicate that Patagonian desertification was not solely a consequence of Andean uplift. Nat. Commun. 5 (3558). http://dx.doi.org/10.1038/ ncomms4558.

Parras, A., Guerstein, G.R., Náñez, C., Pérez Panera, J.P., Cusminsky, G., Griffin, M., 2016. Controles alogénicos durante la depositación de la Formación Monte León y base de la Formación Santa Cruz. In: Mioceno temprano de Cuenca Austral. VII Congreso Latinoamericano de Sedimentología y XV Reunión Argentina de Sedimentología. 130.

Perkins, M.E., Fleagle, J.G., Heizler, M.T., Nash, B., Bown, T.M., Tauber, A.A., Dozo, M.T. 2012. Tephrochronology of the Miocene Santa Cruz and Pinturas Formations, Argentina. In: Vizcaíno, S.F., Kay, R.F., Bargo, M.S. (Eds.), Early Miocene Paleobiology in Patagonia. Hight-Latitude Paleocommunities of the Santa Cruz Formation. Cambridge University Press, pp. 23-40.

Peters, N., Huntington, K., Hoke, G., 2013. Hot or not? Impact of seasonally variable soil carbonate formation on paleotemperature and O-isotope records from clumped isotope thermometry. Earth Planet. Sci. Lett. 361, 208-218.

Quade, J., Cerling, T.E., Bowman, J.R., 1989. Development of the Asian monsoon revealed by marked ecological shift in the latest Miocene in northern Pakistan. Nature 342, 163-166.

Raigemborn, M.S., Gómez-peral, L., Krause, J.M., Matheos, S.D., 2014. Controls on clay mineral assemblages in an Early Paleogene nonmarine succession: Implications for the volcanic and paleoclimatic record of extra-Andean Patagonia, Argentina. J. S. Am. Earth Sci. 52, 1-23.

Raigemborn, M.S., Matheos, S.D., Krapovickas, V., Vizcaíno, S.F., Bargo, M.S., Kay, R.F., Fernicola, J.C., Zapata, L., 2015a. Paleoenvironmental reconstruction of the coastal Monte Léon and Santa Cruz formations (early Miocene) at Rincón del Buque, southem Patagonia: a revisited locality. J. S. Am. Earth Sci. 60, 31-55. https://doi.org/10. 1016/j.jsames.2015.03.001.

Raigemborn, M.S., Krapovickas, Beilinson, E., Zapata, L., 2015b. Sistema de trazas de raíces carbonáticas horizontales en la Formación Santa Cruz, Patagonia Austral, Argentina: evidencias paleoambientales. Tercer simposio latinoamericano de icnología 65. https://slic2015uy.wordpress.com/.

Raigemborn, M.S., Gómez Peral, L., Beilinson, E., Zapata, L., Zucol, A., Krapovickas, V., 2016. Carbonatos pedogenéticos Miocenos y su implicancia paleoambiental a parti del uso de isótopos estables: un ejemplo de Patagonia Austral, Argentina. In: VII Congreso Latinoamericano de Sedimentología y XV Reunión Argentina de Sedimentología. 138.

Retallack, G.J., 2001. Soils of the Past: An Introduction to Paleopedology. Blackwell Science Ltd, London (404 pp).

Retallack, G.J., 2013. Early Cambrian humid, tropical, coastal paleosols from Montana, USA. In: Driese, S.G., Nordt, L.C. (Eds.), New Frontiers in Paleopedology and Terrestrial Paleoclimatology: Paleosols and Soil Surface Analogue Systems. Society for Sedimentary Geology, Special Publication 104. pp. 257-272.

Retallack, G.J., Bestland, E.A., Fremd, T.J., 2000. Eocene and Oligocene Paleosols of Central Oregon. Spec. Pap. Geol. Soc. Am. 344, 1-192. http://dx.doi.org/10.1130/08137-2344-2.1.

Sacristán-Horcajada, S., Arribas, M.E., Mas, R., 2016. Pedogenetic calcretes in early Synrift alluvial systems (Upper Jurassic, West Cameros Basin), northern Spain. J. Sediment. Res. 86, 268-286. http://dx.doi.org/10.2110/jsr.2016.30.

Semeniuk, V., 2010. A note on calcite precipitates as encrustations around sea rush roots and rhizomes and as laminae in high tidal zones of western Leschenault Inlet estuary. J. R. Soc. West. Aust. 93, 195-199.

Smith, GA., 1987. Sedimentology ofvolcanism-induced aggradation influvial basins: examples from the Pacific Northwest, USA. In: Ethridge, F.G., Flores, R.M., Harvey, M.G. (Eds.), Recent Developments in Fluvial Sedimentology. Society of Economic Paleontologists and Mineralogists Special Publication American Association of Petroleum Geologists, pp. 217-228.

Stoops, G., Marcelino, V., Mess, F., 2010. Interpretation of Micromorphological Features 
of Soils and Regoliths. Elsevier, pp. 720.

Strömberg, C.A.E., Dunn, R.E., Madden, R.H., Kohn, M.J., Carlini, A.A., 2013. Decoupling the spread of grasslands from the evolution of grazer-type herbivores in South America. Nat. Commun. 4, 1478. http://dx.doi.org/10.1038/ncomms2508.

Tauber, A.A., 1994. Estratigrafia y vertebrados fósiles de la Formación Santa Cruz (Mioceno Inferior) de la costa atlántica entre las rías del Coyle y de Río Gallegos, Provincia de Santa Cruz. Universidad Nacional de Córdoba, República Argentina.

Tauber, A.A., 1997a. Bioestratigrafía de la formación Santa Cruz (Mioceno inferior) en el extremo sudeste de la Patagonia. Ameghiniana 34, 413-426.

Tauber, A.A., 1997b. Paleoecología de la Formación Santa Cruz (Mioceno inferior) en el extremo sudeste de la Patagonia. Ameghiniana 34, 517-529.

Tunbridge, I.P., 1981. Sandy high-energy flood sedimentation: some criteria for recognition, with an example from the Devonian of SW England. Sediment. Geol. 28, 79-95.

Uchman, A., Slaczka, A., Renda, P., 2012. Probable root structures and associated trace fossils from the Lower Pleistocene calcarenites of Favignana Island, southern Italy: dilemmas of interpretation. Geological Quarterly 56, 745-756. http://dx.doi.org/10. 7306/gq.1052.

Vegas-Vilarrúbia, T., Baritto, F., López, P., Meleán, G., Ponce, M.E., Mora, L., Gómez, O., 2010. Tropical Histosols of the lower Orinoco Delta, features and preliminary quantification of their carbon storage. Geoderma 155, 280-288. http://dx.doi.org/ 10.1016/j.geoderma.2009.12.011.

Verrecchia, E.P., Freytet, P., Verrecchia, K.E., Dumont, J.L., 1995. Spherulites in calcrete laminar crusts: biogenic $\mathrm{CaCO} 3$ precipitation as a major contributor to crust formation. J. Sediment. Res. A65, 690-700.

Vizcaíno, S.F., Kay, R.F., Bargo, M.S., 2012. Early Miocene Paleobiology in Patagonia: High-Latitude Paleocommunities of the Santa Cruz Formation. Cambridge University Press (378 pp).

Wang, H., Greenberg, S.E., 2007. Reconstructing the response of C3 and C4 plants to decadal-scale climate change during the late Pleistocene in southern Illinois using isotopic analyses of calcified rootlets. Quat. Res. 67, 136-142. http://dx.doi.org/10. 1016/j.yqres.2006.10.001.

Wang, Y., Zheng, S., 1989. Paleosol nodules as Pleistocene paleoclimatic indicators. Palaeogeogr. Palaeoclimatol. Palaeoecol. 76, 39-44.

Wang, H., Follmer, L.R., Liu, J.C., 2000. Isotope evidence of paleo-El Niño-southern oscillation cycles in loess-paleosol record in the Central United States. Geology (9), 771-774.

Wang, H., Ambrose, S.H., Fouke, B.W., 2004. Evidence of long-term seasonal climate forcing in rhizolith isotopes during the last glaciation. Geophys. Res. Lett. 31, 10-13. http://dx.doi.org/10.1029/2004GL020207.

Watling, J., Iriarte, J., 2013. Phytoliths from the coastal savannas of French Guiana. Quat. Int. 287, 162-180. http://dx.doi.org/10.1016/j.quaint.2012.10.030.

Wright, V.P., 2007. Calcretes. In: Nash, D., McLaren, S. (Eds.), Geochemical Sediments and Landscapes. Wiley-Blackwell, Oxford, UK, pp. 10-45.

Wright, V.P., Peeters, C., 1989. Origins of some Early Carboniferous calcrete fabrics revealed by cathodoluminescence: implications for interpreting the sites of calcrete formation. Sediment. Geol. 65, 345-353.

Wright, V.P., Tucker, M.E., 1991. Calcretes: An Introduction. In: Wright, V.P., Tucker, M. (Eds.), Calcretes. 1AS Reprint Series 2. Blackwell Scientific Publications, Oxford, pp. $1-22$.

Wright, V.P., Platt, N.H., Marriott, S.B., Beck, V.H., 1995. Sedlmeatary a classification of rhizogenic (root-forme) calcretes, with examples from the Upper Jurassic-lower cretaceous of Spain and Upper cretaceous of southern France. Sediment. Geol. 100, $143-158$.

Watts, N.L., 1980. Quaternary pedogenic calcretes from the Kalahari (southern Africa): mineralogy, genesis and diagenesis. Sedimentology 27, 661-686.

Zachos, J., Pagan, L.M., Sloan, L., Thomas, E., Billups, K., 2001. Trends, rhythms, and aberrations in global climate 65 Mato present. Science 292, 686-693. http://dx.doi. org/10.1126/science.1059412.

Zamanian, K., Pustovoytov, K., Kuzyakov, Y., 2016. Pedogenic carbonates: forms and formation processes. Earth Sci. Rev. 157, 1-17.

Zapata, L., Krapovickas, V., Raigemborn, M.S., Matheos, S.D., 2016. Bee cell trace fossils associations on paleosols from the Santa Cruz formation: Palaeoenvironmental and palaeobiological implications. Palaeogeogr. Palaeoclimatol. Palaeoecol. 459, 153-169. http://dx.doi.org/10.1016/j.palaeo.2016.07.004.

Zucol, A.F., Passeggi, E., Brea, M., Patterer, N.I., Fernández Pepi, M.G., Colobig, M.M., 2010. Phytolith analysis for the Potrok Aike Lake Drilling Project: Sample treatment protocols for the PASADO Microfossil Manual. In: Corbella, H., Maidana, N.I. (Eds.), $1{ }^{\text {a }}$ Reunión Internodos del Proyecto Interdisciplinario Patagonia Austral and $1 \mathrm{er}$ Workshop Argentino del Proyecto Potrok Aike Maar Lake Sediment Archive Drilling Project. Proyecto Editorial PIPA, Buenos Aires, Argentina, pp. 81-84.

Zucol, A.F., Raigemborn, M.S., Strömberg, C.A.E., Crifò, C., Passeggi, E., Bargo, M.S., Vizcaíno, S.F., 2015. Phytolith Analysis From Santa Cruz Formation in Rincon Del Buque Locality (Santa Cruz Province, Argentina). XVI Simp. Argentino Paleobotánica y Palinol. pp. 24-25. http://dx.doi.org/10.13140/RG.2.1.1705.0004. 